\title{
A building integrated solar thermal collector with active steel skins
}

\author{
M Bock \\ School of Architecture and Built Environment, Faculty of Science and Engineering, University of \\ Wolverhampton, WV1 1LY, UK. Email: marina.bock@wlv.ac.uk
}

\begin{abstract}
There is currently a global need to reduce the emission of greenhouse gases. Since buildings are the largest contributor to global warming emissions, improving their energy performance through the implementation of renewable energy technologies is a way forward to reduce energy use and thus carbon footprint. This article presents a new building envelope system that harvests solar energy through the steel skin of the façade of the building. The energy is generated by a steel sandwich panel featuring a modular design that enables full integration into the building envelope of both new constructed and refurbished buildings. The heat transfer means is a glycol and water mixture that flows inside a pipework arrangement embedded into the sandwich panel and connected to a distribution system. This distribution system deploys the energy generated into a buffer tank for further production of heating, cooling and domestic hot water through the use of a heat pump. The elements of this solar system were developed under the framework of the Building Active Steel Skin Envelope (BASSE) project funded by the Research Fund for Coal and Steel (RFCS). A detailed description of the components of the BASSE system as well as how they were developed is presented. Building on satisfactory thermal testing and the successful implementation of the system on a pilot building, the BASSE system was validated. The experimental results have shown that the coefficient of performance (COP) of the heat pump is in between 4.1-4.6. A validated simulation tool estimated that the cladding panel generates $3321.14 \mathrm{kWh} /$ year which is $30.4 \%$ efficiency. Simulation results showed that a 35 BASSE panel installation on residential buildings subjected to temperate climate are Net Zero Energy Buildings (NZEB).
\end{abstract}

Keywords: net zero energy buildings, solar energy, building integrated solar thermal system, sandwich panels, retrofitting, off-site construction

\section{Introduction}

In Europe, about $40 \%$ of greenhouse gas (GHG) emissions come from fossil fuel combustion in the building sector [1]. Since the sector is continuously growing and there are global requirements to achieve a $40 \%$ cut in GHG emissions by 2030 following the Kyoto Protocol, improving energy efficiency of buildings through the implementation of renewable energies are ways to reduce the current high impact of buildings on the environment. To achieve this, and in the context of the European Union (EU), two directives were set out: the Directive 2009/28/EC [2] which defines the 
guidelines on the promotion of the use of renewable energies; and the Directive 2010/31/EC [3] which gives the guidelines on the improvement of the energy performance of buildings and introduces the concept of Net Zero Energy Buildings (NZEB). As defined in the Directive 2010/31/EC [3], NZEB "have high energy performance and the low amount of energy that these buildings require comes mostly from renewable energies, including energy from renewable sources produced on-site or nearby". The NZEB requirement became mandatory in new public buildings since 2018 and from 2020 onwards all new constructed buildings will be required to be NZEB. The complexity of the NZEB concept lies primarily in its implementation arguably due to the lack of clear standardization, unclear definition of terminology, inexistence of business models and not enough guidance on how to quantify the energy building performance (EBP) [1]. Existing research has proposed a harmonisation of the NZEB concept [4-7] as well as methodologies to quantify and assess the EBP [8-10]. Among these studies a few challenges were raised including the implementation of NZEB in existing buildings due to the complexities associated with the renovation sector, cost viability and which renewable resource is available for a particular building and location [11].

Solar energy has been the most popular renewable resource used in renewable energy conversion systems being the most widely employed solar thermal (ST), photovoltaic (PV) and photovoltaic/thermal (PV/T) systems [12-16]. The method of integration of the conversion system into the building envelope has been a matter of concern among architects and building designers as traditional methods such as mechanical fixings can leave the solar components exposed and compromise the aesthetic appearance of the building. With the current global commitments to reduce GHG and buildings required to be NZEB, the application of renewable energy resources in the building sector, in particular solar energy, is expected to rise significantly. Thus, pushing concepts involving building integrated system technologies that make use of solar energy will be the solution to support these objectives [17].

A solar energy conversion system is deemed building (BI) integrated when all its elements are incorporated into the layers of the building envelope and therefore, the BI system cannot be separated from the building envelope unless the entire building element is replaced. BI solar systems are "active" systems, which means that the BI façade elements capture the solar radiation and the heat gains are either subsequently transformed into electricity by the solar façade itself or transported into the building by electrical or mechanical equipment such as pumps or fans [18, 19]. Apart from aesthetics, space savings and increased economic viability of the system are other benefits of BI systems. Methods to integrate the solar components into the building envelope have been explored since late 1990s [20, 21] and comprehensive literature reviews on building integrated solar (BIST) [22], building integrated photovoltaic (BIPV) and building integrated photovoltaic/thermal (BIPV/T) systems [23] are available. 
The scope of these literature reviews does not cover BI system technologies only but also definitions, business models, life cycle assessment studies, economic viability, commercially available products and barriers for market penetration among others. Concerning currently available products and with emphasis being placed upon BIST systems, BIST products can be classified according to three levels [20]: the first level is the type of solar façade which can be either opaque or translucent/transparent; the second level is the thermal resistance between the façade and the ambient air; and finally, according to the heat transfer means. On this basis, second level categories are unglazed, glazed or vacuum while third level categories are air or liquid. Other hierarchy classifications have been proposed $[18,19]$ for solar façades though with emphasis being placed on whether the façade is either opaque or translucent/transparent. These classifications are useful to identify the type of solar system described herein.

This paper presents a novel solar energy conversion system that was developed under the Building Active Steel Skeen Envelope (BASSE) project framework. The developed system is solar thermal type consisting of an unglazed sandwich panel with integrated pipework carrying circulating liquid and a distribution system that mechanically transports with a pump the heat gains into the building and back to the panel. The sandwich panel can be therefore considered a BIST system [24]. Contrary to recently developed active solar system technologies, the BASSE project pushed forward a wellestablished building product, steel sandwich panels thereby enabling immediate market penetration. The BASSE system was developed to operate in three climatic regions typified by the location of the project partners namely Sweden, the United Kingdom and Spain, and with the capability to respond to variable climate conditions and building loads utilising biomimetic principles. The applicability of the BASSE system to both new construction and retrofit was also considered in the framework of the project.

The following sections provide a detailed explanation of the BASSE system as well as the metrics and technologies that were taken into account for its development and design. This article also presents the experimental validation of the BASSE system building on laboratory thermal tests of the panel and implementation of the entire system in a demonstration building in northern Spain. Numerical simulations are also presented to show that the BASSE system can generate enough energy to meet the NZEB requirements of residential buildings located in climatic regions of southern Europe.

\section{Description and development of the BASSE system}

\subsection{Components of the BASSE system}

The BASSE system is comprised of the following three main components, see Figure 1: 
- An energy generating panel: this is the solar collector which consists of a sandwich panel with a low-density foam core, two galvanized steel skins, integrated pipework with circulating fluid into the foam core and an architectural cover sheet.

- A distribution system: the system integrates a heat pump that enhances the energy generated by the panel, a buffer tank that stores heat or cool, a domestic hot water (DHW) tank, a ventilation air recovery system and a three way distribution valve.

- A control system: its main function is to manage the whole system biomimetically that includes programmable logic controllers (PLC), temperature sensors, valves and actuators as well as flow-meters and heat meters.

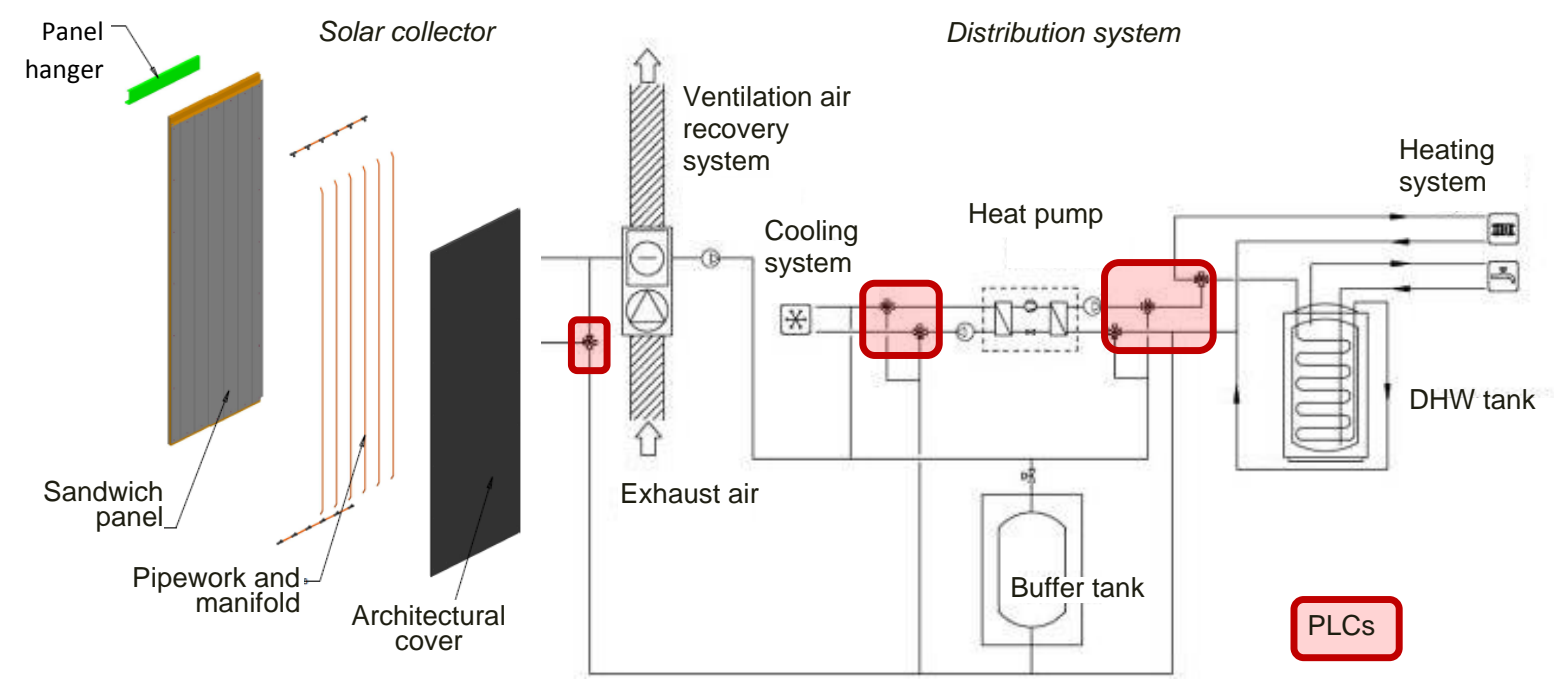

Figure 1. Simplified schematic view of the components of the BASSE system

The BASSE system was designed to provide hot or cold air and domestic heat water (DHW) under the following five working modes: (1) heating; (2) cooling; (3) heating and DHW simultaneously; (4) cooling and DHW simultaneously; and (5) DHW alone. The working mode is selected by a higher level controller, i.e. the building management system (BMS), as the BASSE control system only controls the energy generating panel and the heat pump system.

\subsection{Development of the components}

\subsubsection{Key performance indicators and system requirements}

The components of the BASSE system were developed considering a set of key performance indicators (KPIs) [25-32] which were used to evaluate different conceptual designs for each component alone and establish the initial specification of the system. As part of the development phase, a total of 37 functional and 40 technical KPIs were established in collaboration with potential stakeholders and interested parties. Aspects such as architectural requirements, customer 
acceptability, customer needs, technological viability, cost and design implications were part of the KPIs. A well-known method commonly used in conceptual design of building technologies namely Quality Function Deployment (QFD) was applied to convert qualitative KPIs into measurable parameters [33,34]. In order to be able to appraise possible conceptual designs for each component of the system, the number of KPIs was further simplified by grouping similar KPIs using the QFD method. Therefore, the components of the BASSE system were developed taking into account the functional and technical KPIs shown in Table 1.

Not included in the list of KPIs but yet demanded by the general objectives of the BASSE system were the following 14 system requirements: energy balance between the energy provided by the system and the building loads; improved energy efficiency by a storage and management system; multi-functionality; integrated with existing façade technologies; smart solar collector; intelligent management system; biomimetic operation; response to user demand; industrialised concept; off-site, pre-engineering and modular; plug and play; lightness; use of renewable resources; and applicable to new or refurbished buildings.

Table 1. BASSE system specification KPIs

\begin{tabular}{|c|c|c|c|}
\hline Component & Key Performance Indicator (KPI) & Target Values & Units \\
\hline \multirow{8}{*}{$\begin{array}{l}\text { System level } \\
\text { (common to } \\
\text { all) }\end{array}$} & Normalised cost & $<0.15$ & $€ / \mathrm{kWh}$ \\
\hline & & $<0.0531(\mathrm{UK})$ & \\
\hline & Normalised operating Cost & $<0.0754$ (Spain) & $€ / \mathrm{kWh}$ \\
\hline & & $<0.1227$ (Sweden) & \\
\hline & Carbon footprint (Manufacture) & Depends on size of system & $\mathrm{kg} / \mathrm{yr}$ \\
\hline & $\begin{array}{l}\text { Interaction with building features (Architectural } \\
\text { Adaptability) }\end{array}$ & & rating \\
\hline & Ease of maintenance & & rating \\
\hline & Manufacturability & & rating \\
\hline \multirow{2}{*}{$\begin{array}{l}\text { Solar } \\
\text { collector }\end{array}$} & Specific annual solar yield & $>300$ & $\mathrm{kWh} / \mathrm{m}^{2}$ \\
\hline & Thermal efficiency & $>50$ & $\%$ \\
\hline \multirow{5}{*}{$\begin{array}{l}\text { Energy } \\
\text { storage tank }\end{array}$} & Energy density of active storage material & $>23.3$ & $\begin{array}{l}\mathrm{kWh} / \mathrm{kg}, \\
\mathrm{kWh} / \mathrm{m}^{3}\end{array}$ \\
\hline & Energy storage efficiency & $>70 \%$ & $\%$ \\
\hline & Rate of energy discharge & $\begin{array}{l}\text { Depends on building and } \\
\text { location }\end{array}$ & $\mathrm{W}$ \\
\hline & Temperature at which energy is stored & $>20$ & ${ }^{0} \mathrm{C}$ \\
\hline & Temperature at which energy is released & $<20$ & ${ }^{0} \mathrm{C}$ \\
\hline \multirow{4}{*}{$\begin{array}{l}\text { Heating } \\
\text { cooling } \\
\text { system } \\
\text { including } \\
\text { heat pump }\end{array}$} & Capacity of heating system & $\begin{array}{l}\text { Depends on building and } \\
\text { location }\end{array}$ & $\mathrm{W}$ \\
\hline & Coefficient of Performance (COP) & $>3.0$ & ratio \\
\hline & Cooling Capacity & $\begin{array}{l}\text { Depends on building and } \\
\text { location }\end{array}$ & $\mathrm{W}$ \\
\hline & Energy efficiency ratio (EER) & $>2.0$ & ratio \\
\hline
\end{tabular}


Having defined the KPIs and system requirements, different concepts were explored in relation to the energy generating panel (solar collector), power technologies employing a heating and cooling heat pump and energy storage technologies. With the exception of the normalised operating cost, which is based on normalised tariffs [32], target values for each KPI were set out; see Table 1, to be able to define the specifications of each component. The following describes on which basis a preferred solution was taken to the final concept stage [35].

\subsubsection{Energy generating sandwich panel}

The energy generating panel is part of the façade of the building, and thus as a vertical element is exposed to lower irradiance. In order to outweigh this disadvantage, a ST conversion system was selected over PV because it has higher thermal efficiency. A total of seven concepts were developed and evaluated against the target values of the above KPIs, see Figure 2. The seven explored concepts were:

- Concept 1: sandwich panel solar collector (SPSC) with pipework integrated in the lowdensity foam core, see Fig. 2 (a). Three possible pipework arrangements as shown in Fig. 2 (d) were explored including horizontal serpentine, vertical serpentine and vertical parallel. Circulating liquid is a mixture water glycol as for all of the concepts listed below.

- Concept 2: sandwich panel with transpired solar collector (TSC). TSC are a relatively new solar thermal system made of perforated solar absorbent steel sheets installed with an offset from the wall or roof to create an air cavity that absorbs the heat transferred by the perforated sheet [36]. Since air is the main heat transfer medium and air has a lower specific heat transfer, this design is less thermally efficient compared to designs where the main medium is liquid.

- Concept 3: SPSC with integrated pipework inside the foam core, the parallel variant only, combined with a glazed TSC. The purpose of this concept was to use two mediums of heat transfer, liquid and fluid, for different application. This is an advantage but a disadvantage at the same time because dealing with two circuits can be rather complex. Installation was also identified as a main issue as opposed to heat transfer which is enhanced by the glazing provided.

- Concept 4: SPSC with recesses within one of the steel skins whereby pipework is integrated following a parallel arrangement and combined with a glazed TSC. Mounting the pipework outside the foam core increases exposure to solar radiation thereby increasing energy harvested but again mounting and dealing with two circuits can be difficult.

- Concept 5: SPSC with pipework integrated on one of its steel skins and covered with an architectural steel sheet; see Fig. 2 (b). Likewise in concept 1 three possible pipe 
arrangements were examined. Potential disadvantages identified in this design were manufacture and heat transfer between the architectural cover sheet and pipework.

- Concept 6: same as concept 5 but with an offset architectural cover sheet that creates a cavity, see Fig. 2(c). This will result in the air inside the cavity being the main heat transfer medium.

- Concept 7: same as concept 6 but replacing the architectural cover sheet by a perforated steel skin similar to that used in the TSC design. This design allows the ventilation needs of the building to be met but has heat transfer issues due to the perforated steel skin not being in contact with the pipework.

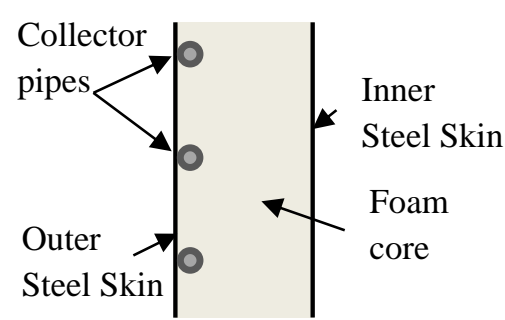

(a) SPCS with embedded pipework

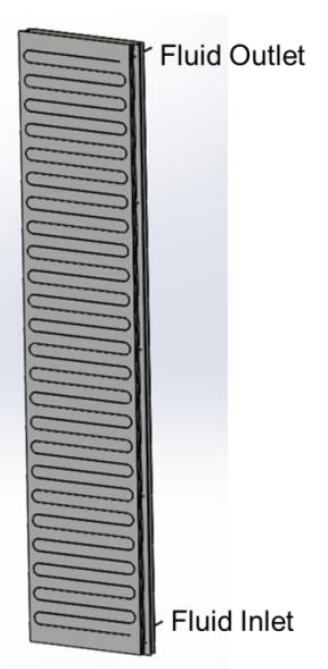

Horizontal serpentine

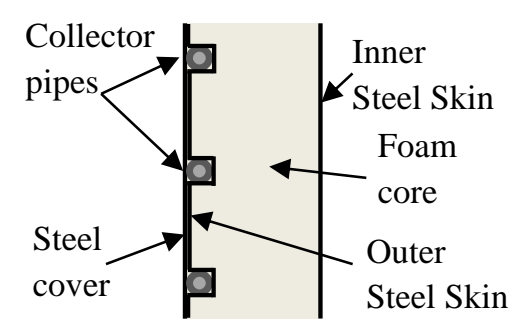

(b) SPCS with pipework mounted externally

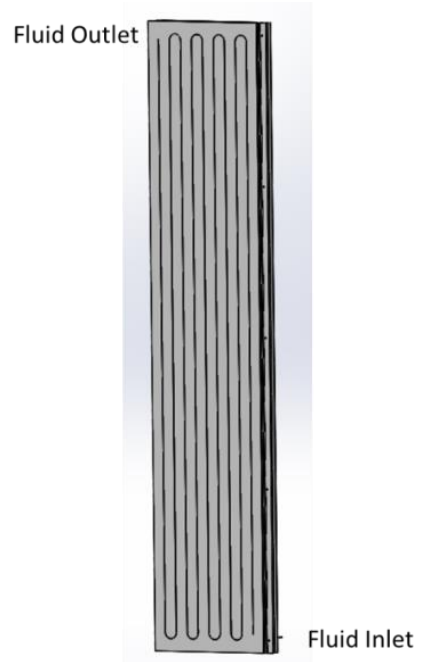

Vertical serpentine

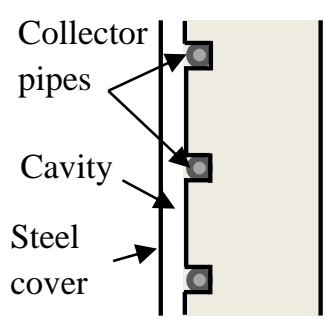

(c) SPCS with pipework mounted externally and offset steel sheet

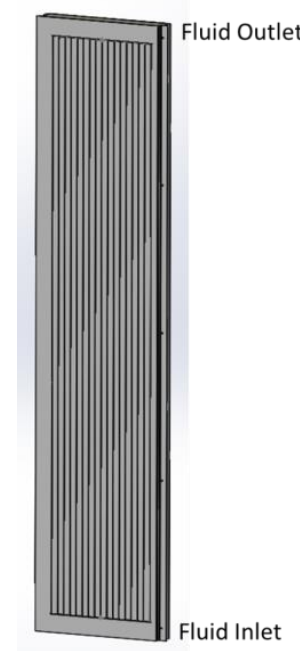

Parallel

(d) Pipework arrangements taken into consideration

Figure 2. Some of the features charactering the seven concepts developed for the energy generating

sandwich panel

The seven concepts were evaluated using a decision making qualitative tool namely Pugh matrix [37]. For the evaluation, the following aspects were considered: annual solar yield, efficiency, normalized cost, normalized operating cost, carbon footprint in the manufacture, architectural adaptability, ease of maintenance and manufacturability. The evaluation showed that concepts 1, 5 and 6 ranked the highest scores. However, concept 6 using SPSC with offset steel cover was disregarded due to expected inefficient heat transfer between the architectural cover and pipework. Since the cover is the 
surface that receives the solar radiation an offset is to result in the cavity not efficiently transferring to the pipework the heat harvested from the sun.

Computer fluid dynamics modelling with ANSYS CFX was conducted to compare concepts 1 and 5. The geometry of the sandwich panel was approximated to a rectangular parallelepiped whilst the pipe length was fixed at $1 \mathrm{~m}$. Solid (i.e. sandwich panel) and fluid (i.e. circulating liquid and air) domains were defined with parameters shown in Tables 2 and 3, respectively, where the nature of the variable is included. The results are shown in Figure 3 where it is observed that the heat transfer achieved by concept 5 is $35 \%$ higher than that achieved by concept 1 . This was attributed to the pipework area in contact with the external architectural cover which was larger in concept 5 [38]. One aspect worth to mention concerns the pipework arrangement. Although simulations showed that the serpentine arrangement provides a higher output temperature whilst requiring less material, see section 4 , the parallel arrangement was preferred. This was not only because of being more suited for modular assembly but also to enable several panels to be interconnected and ultimately generate a greater overall power out more likely to meet the building energy demands. On this basis, further thermal analysis was conducted so as to optimise concept 5 with parallel arrangement whilst considering the impact of various parameters on the thermal performance of the energy generating panel including various pipe materials, spacings, pipe wall thickness, thickness of the steel skins and working fluid types among others were accounted for [38]. The validation is presented in section 4 as part the thermal tests conducted on four solar collector prototypes.
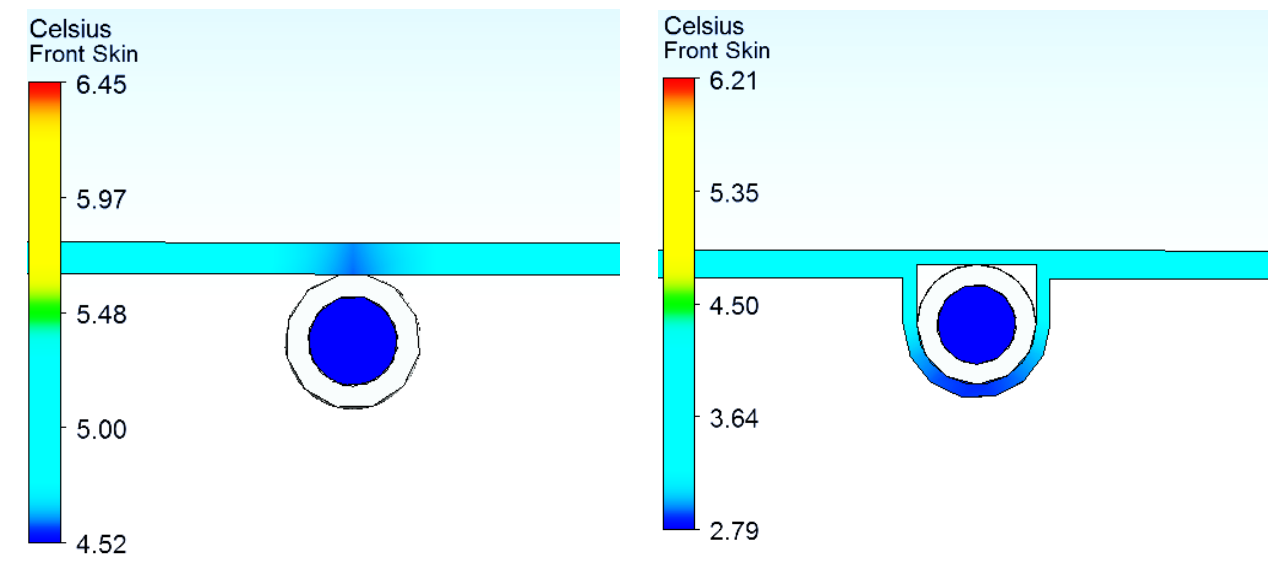

Figure 3. Temperature in ${ }^{\circ} \mathrm{C}$ of the steel skin for concept 1 (left) and concept 5 (right) 
Table 2 - Simulation parameters for solid domain

\begin{tabular}{ll}
\hline Parameter & Value \\
\hline Architectural cover sheet & coated steel \\
Material & Flat \\
Profile & $0.7 \mathrm{~mm}$ \\
Thickness & 0.8 \\
Absorptivity & 0.28 \\
Emissivity & \\
\hline Sandwich panel outer skin & galvanized steel \\
Material & recessed pipe slots \\
Profile & $0.7 \mathrm{~mm}$ \\
Thickness & 0.8 \\
Absorptivity & 0.28 \\
Emissivity & \\
\hline Sandwich panel insulation & PUR \\
Material & $70 \mathrm{~mm}$ \\
Thickness & $0.02 \mathrm{~W} / \mathrm{m} \mathrm{K}$ \\
Thermal conductivity & \\
\hline Sandwich panel inner skin & Steel \\
Material & $0.7 \mathrm{~mm}$ \\
Thickness & \\
\hline Pipe & Conductive Plastic \\
Material & $10 \mathrm{~mm}$ \\
External diameter & $1 \mathrm{~mm}$ \\
Wall thickness & $160 \mathrm{~mm}$ \\
Spacing & $3 \mathrm{~W} / \mathrm{m} \mathrm{K}$ \\
Thermal conductivity & \\
\hline
\end{tabular}

Table 3 - Simulation parameters for fluid domain at $25^{\circ} \mathrm{C}$

\begin{tabular}{ll}
\hline Parameter & Value \\
\hline Fluid type & $50 \%$ Ethylene Glycol \\
Fluid density & $1083.4 \mathrm{~kg} / \mathrm{m}^{3}$ \\
Fluid specific heat capacity & $3.267 \mathrm{~kJ} / \mathrm{kg} \mathrm{K}$ \\
Fluid dynamic viscosity & $3.39 \mathrm{mPa} \mathrm{s}$ \\
Fluid thermal conductivity & $0.37 \mathrm{~W} / \mathrm{m} \mathrm{K}$ \\
\hline
\end{tabular}

The solar collector prototypes were specified as a sandwich panel with two galvanised $0.7 \mathrm{~mm}$ steel skins and a $70 \mathrm{~mm}$ core of polyurethane rigid foam (PUR). The selected pipework arrangement was vertical parallel pipes running through the recesses within one of the steel skins connected to two horizontal manifolds. The pipework was made of polybutylene featuring $1 \mathrm{~mm}$ wall thickness, $10 \mathrm{~mm}$ outer diameter and $160 \mathrm{~mm}$ spacing as shown in Figure 4. The circulating liquid mixture combined water with $50 \%$ by volume ethylene glycol antifreeze. The architectural cover was a $0.7 \mathrm{~mm}$ coated steel sheet. 

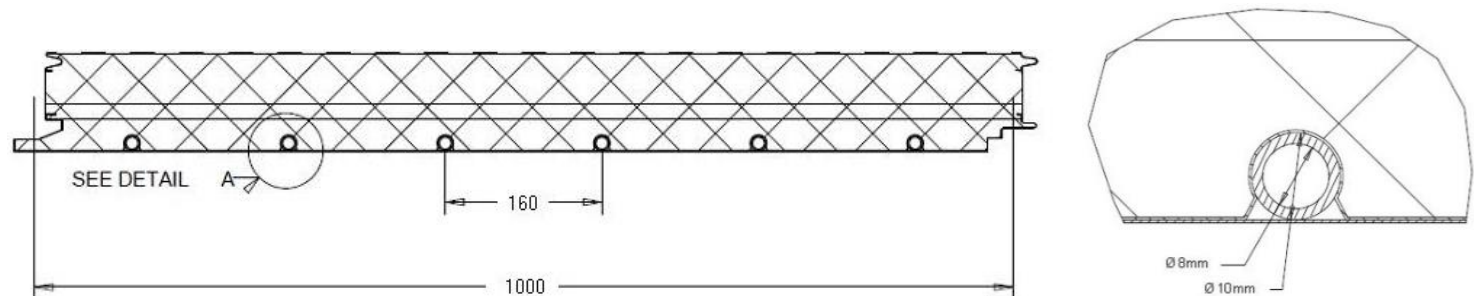

Figure 4. Cross-section of the concept (left) and detail A showing cross-section of the pipe (right)

In terms of manufacturability of the panels, all the panel sub-assemblies were designed to achieve full modularity and therefore be suitable for offsite manufacture and ease assembly on site. The sandwich panel itself is already adequate for industrial production in a continuous line but the pipework and architectural cover must be attached manually. The method to attach the architectural cover onto the steel skin is by using screw fixings. Manufacturing methodologies for the panel and all its sub parts were investigated in [39] and [40]. Methods of installation were also explored in [39] where a series of construction details for application to both new buildings and refurbishments were developed and subsequently implemented and validated in the demonstration building described in section 4 . The production process of the energy generating panel was simulated by using Flexsim [40]. Considering six possible simulation scenarios the production time of one panel was estimated to be between 33 and 44 minutes.

\subsubsection{Heat pump based on power technologies including heating and cooling}

Through the selection of heating and cooling technologies for the heat pump system the ultimate objective was to meet the needs of the building occupants whether they are heat or cold. In the framework of the development of the BASSE system, the purpose of the heating technologies was to enhance the heat captured by the energy generating sandwich panel while the objective of the cooling technology was to absorb heat from the interior of the building and transfer it back to the panel.

Electrically powered vapour compression heat pumps and thermoelectric heat pumps were considered as heating technologies. Natural gas or oil powered technologies were not explored because of being less widely available [41, 42]. The cooling technologies reviewed were air conditioning systems with heat pumps operating in reverse mode to capture energy from the inside of the building, absorbent only systems and adsorbent cooling systems [43]. Considering the KPIs set out to specify the requirements of the BASSE system and its sub-assemblies, the main criteria to select the appropriate heating and cooling technologies was capacity and efficiency. For the heating technologies these are capacity of heating measured in watts and coefficient of performance (COP) while for the cooling technologies these are capacity of the cooling system in watts and cooling energy efficiency ratio (EER). The COP was determined dividing the power output of the heat pump by the power required to operate the heat pump while the EER was calculated dividing the cooling power output from the heat pump by the power required to operate the heat pump. The resulting COP and EER are 
dimensionless parameters. Other deciding factors such as operational costs [44] were not considered at this development phase.

Among the heating systems, electrically powered vapour compression heat pumps, which use a vapour compression cycle to take low grade energy (i.e. that generated by the sandwich panel) to high grade energy, were preferred over thermoelectric heat pumps because they present greater capacity and are more versatile (i.e. $>500 \mathrm{~W}$ and $\mathrm{COP}$ in the range of $2.5-4.0$ ). They are also the preferred energy of source for the majority of European countries [42]. The circulating fluid would be same as that used in the energy generator panel. The main disadvantage of vapour compression heat pumps as opposed to thermoelectric heat pumps is that they cannot operate in reverse mode to supply cold. However, it is possible to overcome this issue by adding a reversible valve, see Figure 5.

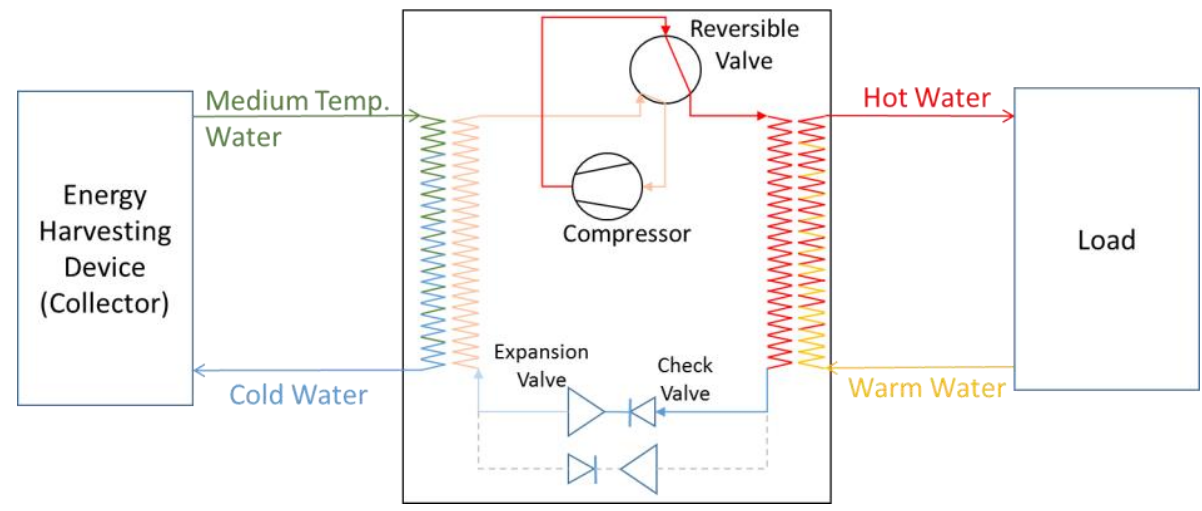

Heating mode

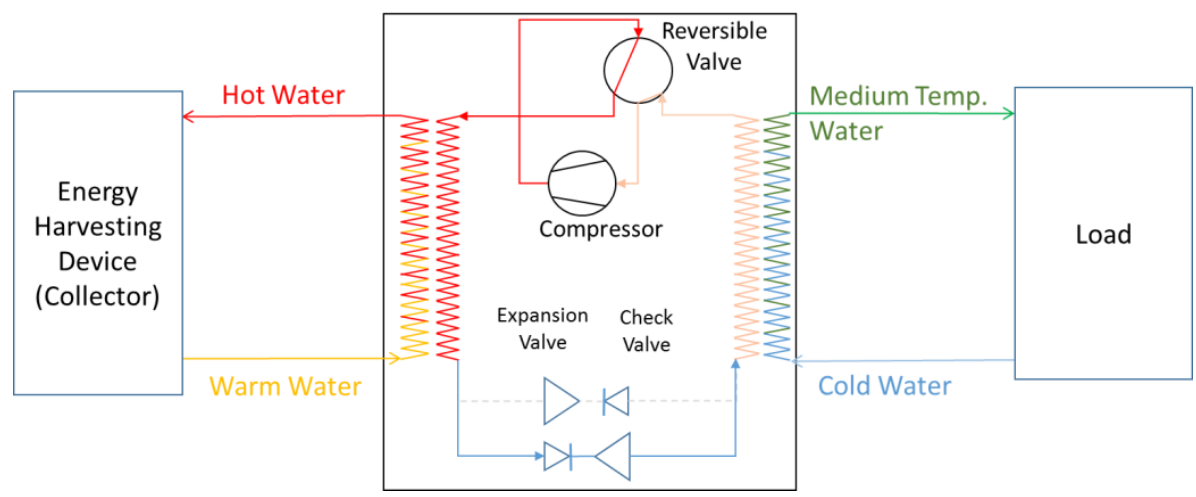

Cooling mode

Figure 5. Vapour compression heat pumps in heating mode (top) and cooling mode (bottom)

The implementation of such reversible valve allows vapour compression heat pumps to behave like an air conditioning system with EER in the 2 to 5 range. One aspect that was considered in the development phase of the BASSE system was to combine vapour compression heat pumps with absorption and or adsorption cooling systems to even more increase the EER as these systems, which are in fact relatively new, are able to utilise any available waste heat. This would be useful in industrial buildings such as factories since they are a major producer of heat [45]. However, this 
option was ruled out because developing all these systems to a level that is suitable for incorporation into the BASSE system, in their present technological stage, would require too much development work.

\subsubsection{Energy storage technologies}

The following three energy storage concepts were assessed: sensible heat storage using a hot water cylinder, phase change materials incorporated in the sandwich panel and thermochemical storage systems based on exothermic reversible reaction.

Having assessed all alternatives, the technology taken forward was sensible heat storage using a hot water cylinder because it provides a good balance between KPIs, simplicity, reliability and ease of implementation. With regard to the other two storage technologies, it was concluded that thermochemical storage systems would not ensure a complete charging of the storage system because they operate at higher temperatures than that set out in the KPIs, see Table 1 (i.e. about $70{ }^{\circ} \mathrm{C}$ are required). On the other hand, for phase change materials the temperature at which the energy is required to be stored and subsequently released must match the transformation temperature range of the phase change material which is difficult to control. At its current stage, technologies associated with phase change materials are too immature to be introduced into the BASSE system.

\subsubsection{Final concept and conclusions}

Having assessed a wide range of existing technologies for the BASSE system, the final concept therefore utilises SPSC with parallel arrangement of pipes covered with an architectural steel sheet, reversible vapour compression heat pump and sensible hot water storage tank.

The novelty of the BASSE project is the implementation of biomimetic and the need to enhance the heat generated by the energy generating sandwich panel. Indeed existing technologies require development work anyway but in the framework of the project, it was decided to bring forward well implemented existing technologies and leave for future research less well established solutions such as phase change materials.

\section{Specification and simulation of the final concept}

\subsection{Description of the simulation tool}

Having decided the technologies of the final concept, sizing of each of the components was undertaken to ultimately predict an estimation of the energy generated by the BASSE system. To achieve this, a computer aid tool containing engineering calculations and numerical results obtained with the above mentioned ANSYS CFX results was developed [46]. Ultimately, the tool aimed to provide the specifications of the BASSE system for implementation into the Kubik Building, an 
experimental building facility located at the northern coast of Spain that was conceived to test new concepts and services for application to buildings, see section 5 .

The computer aid tool was structured in three levels:

(i) Panel specification level: this level aimed to estimate the skin temperature working range of the energy generating panel, how it affects the COP of the heat pump and ultimately size the energy generating panel.

(ii) Building level: considering the five working modes of the BASSE system, this level aimed to size all the BASSE sub-assemblies.

(iii) Detailed level: this level was conceived to estimate how the BASSE systems components from the inside of the building behave and interact between them.

The inputs needed by the latest levels of the tool were based on the outputs provided by the previous one. All the stages of the tool also required support parameters that could relate for instance to the KPIs and or engineering assumptions. The following gives an example of some of the inputs required by the tool: building location (i.e. meteorological data, radiation, temperature, etc.), the number of energy generating panels and total area, the ventilation rate within the area to be heated or cooled, the energy demand for heating, cooling and DHW, etc.

The heat transfer model between the energy generating panel (solar collector) and heat pump implemented in the computer aid tool for the panel specification level is shown in Figure 6. In this figure, $T_{\text {low }}$ is the input fluid temperature, $+\mathrm{Q}_{2}$ is the heat absorbed by the pipes, $-\mathrm{Q}_{2}$ is the heat extracted from the fluid by the heat pump, $\mathrm{Q}_{1}$ is the heat required which depends on the building type and application and $\mathrm{W}$ is the electric work determined as $\mathrm{W}=\mathrm{Q}_{1} / \mathrm{COP}$ where the $\mathrm{COP}$ depends on the pump used, determined as $\mathrm{Q}_{2}=\mathrm{Q}_{1}-\mathrm{W}$ is the heat absorbed per pipe. The main objective was to maximise the heat absorbed by the pipes $+\mathrm{Q}_{2}$ whilst optimising the COP of the pump (i.e. reducing W). There were two ways to achieve this latter objective. First, by decreasing as much as possible the output temperature $\mathrm{T}_{\text {high }}$ or second, by increasing the input temperature $\mathrm{T}_{\text {medium }}$ (i.e. the temperature coming out from the collector). Since $\mathrm{T}_{\text {high }}$ is a building dependant parameter that cannot be modelled, the latter option was preferred. Considering that the maximum $\mathrm{T}_{\text {medium }}$ that can be achieved is the temperature of the architectural sheet $\mathrm{T}_{\text {skin }}$ and imposing that the input temperature $\mathrm{T}_{\text {low }}>0{ }^{0} \mathrm{C}$ (i.e. to avoid freezing of the circulating liquid if that liquid is water) the adequate flow rate $\dot{\mathrm{m}}_{1}$ can be determined through $+\mathrm{Q}_{2}=\dot{\mathrm{m}}_{1} \mathrm{c}_{\mathrm{p}}\left(\mathrm{T}_{\text {medium }}-\mathrm{T}_{\text {low }}\right)$ where $\mathrm{c}_{\mathrm{p}}$ is the specific heat capacity of the water/ethanol mixture and is equal to $4207 \mathrm{~J} / \mathrm{kg} \mathrm{K}$. Having determined the flow rate and following computer fluid dynamics modelling with ANSYS CFX as above, it is possible then to find the ideal length pipe $\mathrm{L}_{\text {pipe }}$. This will enable to subsequently determine the total number of pipes necessary to meet + Q2, the total number of panels needed and ultimately assess the feasibility of the system for various building applications and climate regions. 


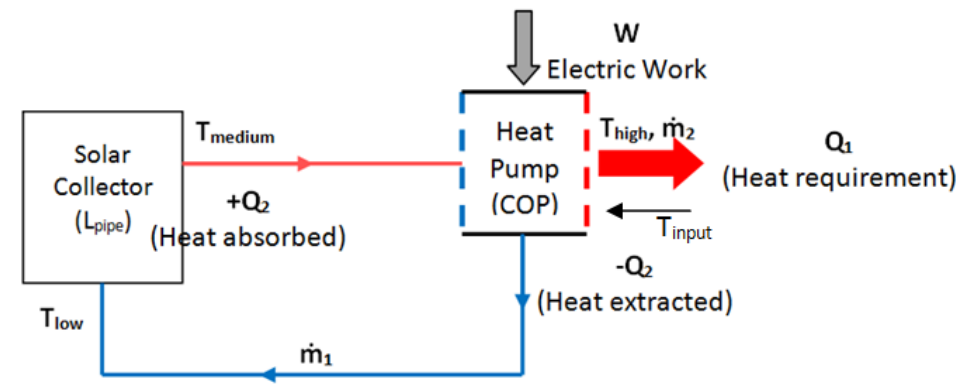

Figure 6 . Heat transfer model between the energy generating panel and the heat pump

\subsection{Simulation considerations}

In the context of specifying the final concept for residential applications, there were two key input parameters: the typology of the building and its location. The building typology was defined within the framework of a major rehabilitation project in "La ciudad de los Ángeles" in Madrid. A 5 storey and 10 apartments of approximately $50 \mathrm{~m}^{2}$ each with three external façade faces was defined as the "target building", see Figure 7. The overall building footprint is $16.34 \mathrm{~m} \times 7.55 \mathrm{~m}\left(123.36 \mathrm{~m}^{2}\right)$ with a total height of $16 \mathrm{~m}$ and floor to floor distance of $2.77 \mathrm{~m}$. The construction of this type of building is concrete frame which is in-filled by a brick cavity wall $0.3 \mathrm{~m}$ thick with no insulation in the cavity. A breakdown of the envelope of the apartment building is provided in Table 4 showing areas and transmittance values while Table 5 gives details of the window openings in the building. The North West external wall is a party wall with the adjacent building. The appliance used in the typical apartment was heating and DHW in the form of standard natural gas boiler with $24 \mathrm{~kW}$ rated power and $56.8 \%$ efficiency. No provision was used for cooling. The $\mathrm{CO}_{2}$ emissions in $\mathrm{kgCO}_{2} / \mathrm{m}^{2}$ year by element were as follows: 59.76 for the whole building, 50.33 for heating, 4.77 for cooling and 4.66 for DHW.
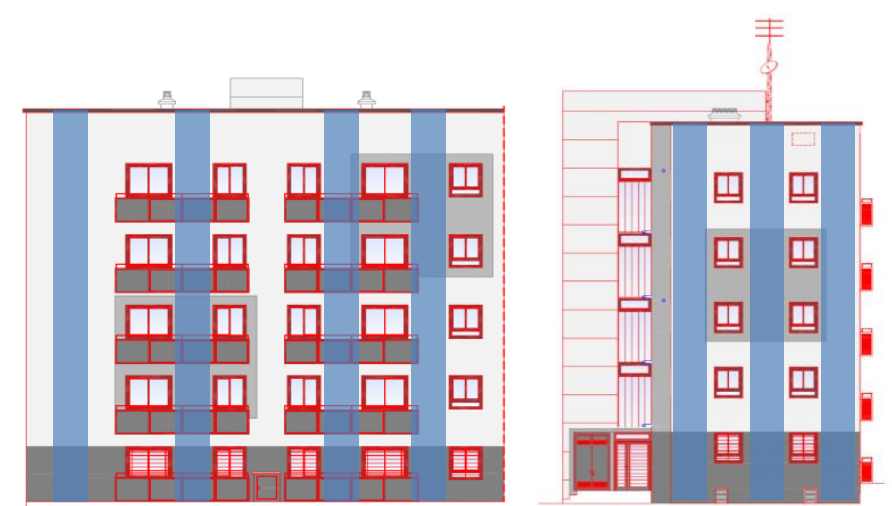

Figure 7. South West (left) and South East (right) façades of the target building incorporating vertical panels shown in blue 
Table 4 - Breakdown of wall elements of the target building

\begin{tabular}{ccccccc}
\hline Wall & $\begin{array}{c}\text { Length } \\
(\mathrm{m})\end{array}$ & $\begin{array}{c}\text { Height } \\
(\mathrm{m})\end{array}$ & Area $\left(\mathrm{m}^{2}\right)$ & Window area $\left(\mathrm{m}^{2}\right)$ & Net wall area $\left(\mathrm{m}^{2}\right)$ & $\begin{array}{c}\text { Transmittance } \\
\left(\mathrm{W} / \mathrm{m}^{2} \mathrm{~K}\right)\end{array}$ \\
\hline North East & 15.74 & 15.14 & 238.30 & 47.70 & 190.60 & 1.64 \\
South West & 15.74 & 15.14 & 238.30 & 36.00 & 202.30 & 1.64 \\
South East & 6.95 & 15.14 & 105.22 & 12.00 & 93.22 & 1.64 \\
North West & 6.95 & - & - & - & - & - \\
\hline
\end{tabular}

Table 5 - Breakdown of openings for the target building

\begin{tabular}{cccccc}
\hline Wall & Number of openings & Width $(\mathrm{m})$ & Heigth $(\mathrm{m})$ & Total area $\left(\mathrm{m}^{2}\right)$ & Transmittance $\left(\mathrm{W} / \mathrm{m}^{2} \mathrm{~K}\right)$ \\
\hline North East & 5 & 1.05 & 1.20 & 6.30 & 5.7 \\
North East & 10 & 0.60 & 0.9 & 5.40 & 5.7 \\
North East & 10 & 2.00 & 1.8 & 36.00 & 5.7 \\
South West & 10 & 1.50 & 1.20 & 18.00 & 3.30 \\
South West & 15 & 1.00 & 1.20 & 18.00 & 5.70 \\
South East & 10 & 1.00 & 1.20 & 12.00 & 5.70 \\
\hline
\end{tabular}

Location wise, three different climatic regions including southern Europe, temperate Europe and northern Europe were considered (i.e. Madrid, Leicester and Malmö). In line with past thermal simulations [47-49], meteorological data corresponding to these three locations was transformed into sensible data by using TRNSYS [50]. Temperature and irradiance expressed as an hourly rate was considered as meteorological data.

Following the above considerations, the computer aid tool was run considering the following: the target building has 35 energy generating panels $\left(108.59 \mathrm{~m}^{2}\right)$ installed on the façade; the target Heat Pump's average COP is 4 ; the internal desired building temperature is $21^{\circ} \mathrm{C}$, the temperature at which heating is activated is $16^{\circ} \mathrm{C}$, the consumption of the DHW is $2500 \mathrm{kWh} / \mathrm{dwelling}$.

\subsection{Simulation results}

The results of the simulation are depicted in Figure 8 where a pie chart has been presented for each of the locations upon consideration. The charts show in \% a breakdown of the energy balances of the building including the energy harvested by the energy generating panels, the energy recovered from the building ventilation system, the energy enhanced by the heat pump and the supplementary heating needed to meet the building loads. The results show that the energy generated by the BASSE system meets the building loads of the "target building" when this building is located in Madrid thereby achieving a NZEB. Regarding the cases of Leicester and Malmö, simulation results show that along with the BASSE system, and additional $1 \%$ and $7 \%$ of supplementary energy respectively is required. Other important aspects to highlight are that the quantity of energy harvested is lower in colder climates while the quantity of heat recovered from ventilation increases in colder climates. 


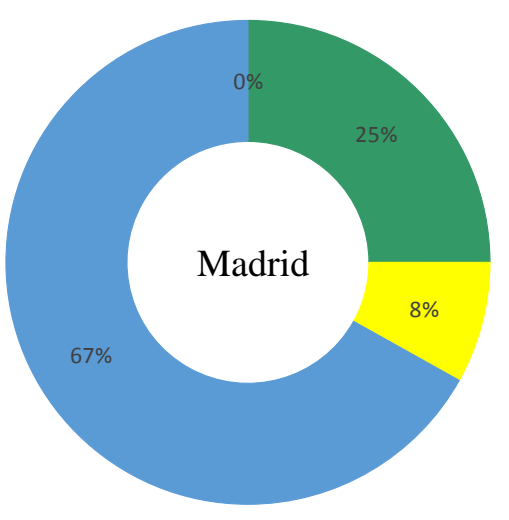

Supplementary heating

Energy recovered from the exhaust air
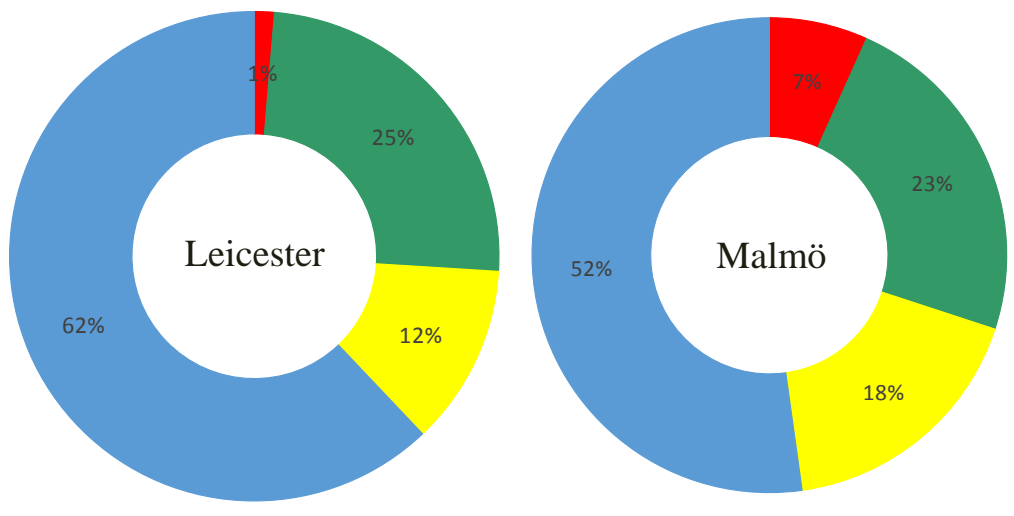

Electricity to heat pump (excluding pumps)

Energy harvested from the active panels

Figure 8. Breakdown of energies for the target building and 35 active BASSE panels

A second simulation considering 45 energy generating panels $\left(139.61 \mathrm{~m}^{2}\right)$ for the Leicester and Malmö cases showed that while providing the former with 10 additional panels is enough to enable a Net Zero Energy Balance, a 5\% supplementary energy is yet required by the latter case.

\subsection{Cost analysis and payback periods}

Following the numerical simulations, a cost analysis was carried out to measure whether investing in more BASSE panels is effective or not. The cost of one BASSE energy generating panel was estimated at $92.7 € / \mathrm{m}^{2}$ out of which $45 € / \mathrm{m}^{2}$ relate to the plain sandwich panel and thus $47.7 € / \mathrm{m}^{2}$ to the sub-assemblies such as pipework and cover. The cost of the remaining parts of the BASSE system including a DHW tank, a buffer, the ventilation heat recovery exchanger and circulating liquid mix was estimated at $16000 €$. Considering therefore that the cost of a conventional sandwich panel is 37 $€$, the extra over cost of a 35 panel installation is estimated at $21852 €$ while $23524 €$ for a 45 panel installation. A detailed cost breakdown is given in Table 6 .

The estimated payback period for the target building and installation of 35 panels was 7.3 years for Madrid, 6 years for Leicester and 6.2 years for Malmö. In the case of a 45 panels installation for Leicester and Malmö the payback figures are 6.4 years, 6.5 years, respectively [51]. It is therefore observed that payback is higher when the climate gets warmer. This is because the energy required for running the BASSE system decreases less than the energy demand of the building. 
Table 6 - Breakdown of costs of the BASSE system

\begin{tabular}{|c|c|c|c|c|}
\hline \multirow{2}{*}{$\begin{array}{l}\text { Components } \\
\text { BASSE energy generating panel }\end{array}$} & \multirow[t]{2}{*}{ Description } & \multicolumn{3}{|c|}{ Cost } \\
\hline & & & & \\
\hline BASSE composite panel & Trimapanel modified $70 \mathrm{~mm}$ thick & & 45.0 & $€ / \mathrm{m}^{2}$ \\
\hline Architectural cover & Colorcoat Prisma & & 12.0 & $€ / \mathrm{m}^{2}$ \\
\hline Pipes & $1.2 \mathrm{~m}$ long $10 \mathrm{~mm}$ diameter & & 2.4 & $€ / \mathrm{m}^{2}$ \\
\hline Manifold & 50 Simple pipe based manifold & & 33.3 & $€ / \mathrm{m}^{2}$ \\
\hline & & TOTAL & 92.7 & $€ / \mathrm{m}^{2}$ \\
\hline 35 BASSE panel installation & Area of installation $105 \mathrm{~m}^{2}$ & & 9733.5 & $€$ \\
\hline 45 BASSE panel installation & Area of installation $135 \mathrm{~m}^{2}$ & & 12514.5 & $€$ \\
\hline 160 BASSE panel installation & Area of installation $480 \mathrm{~m}^{2}$ & & 44496 & $€$ \\
\hline Plain sandwich panel & Trimapanel $70 \mathrm{~mm}$ thick & & 37 & $€ / \mathrm{m}^{2}$ \\
\hline Difference in cost & Cost of BASSE - plain sandwich panel & & 55.7 & $€ / \mathrm{m}^{2}$ \\
\hline \multicolumn{5}{|l|}{ Over costs for BASSE panel } \\
\hline 35 BASSE panel installation & & & 5852 & $€$ \\
\hline 45 BASSE panel installation & & & 7524 & $€$ \\
\hline 160 BASSE panel installation & & & 26752 & $€$ \\
\hline \multicolumn{5}{|l|}{ Other parts of the BASSE system } \\
\hline Heat pump & 20-25 kW heating power model NIBE F1155-16 & & 5500 & $€$ \\
\hline Buffer & 5001 volume model NIBE UKV 500 & & 2500 & $€$ \\
\hline $\begin{array}{l}\text { Ventilation heat recovery } \\
\text { exchanger }\end{array}$ & Model NIBE FLM & & 2500 & $€$ \\
\hline Extra plumbing & Connecting copper pipes & & 4000 & $€$ \\
\hline Ethanol/fluid mix & $50 \%$ water $50 \%$ ethanol & & 1500 & $€$ \\
\hline & & TOTAL & 16000 & $€$ \\
\hline \multicolumn{5}{|l|}{ Over costs for BASSE system } \\
\hline 35 BASSE panel installation & & & 21852 & $€$ \\
\hline 45 BASSE panel installation & & & 23524 & $€$ \\
\hline 160 BASSE panel installation & & & 42752 & $€$ \\
\hline
\end{tabular}

\subsection{Simulation, cost and payback for application to commercial buildings}

Apart from examining the viability of the BASSE system for application to residential buildings, the computer aid tool was also utilised to model a commercial building with 160 energy generating panels located in Leicester. The resulting balances of energy were as follows: energy harvested by the energy generating panels was $31 \%$, the energy recovered from the building ventilation system was $43 \%$, the energy enhanced by the heat pump was $25 \%$ and the supplementary heating needed to meet the building loads was only $1 \%$. The extra over cost of a 160 panel installation on a commercial building was estimated at $42752 €$ resulting in a payback period of 0.7 years.

\subsection{Sizing of the system for validation}

The computer aid tool was finally used to size the BASSE system in full for final validation. This included the sandwich energy generating panel and the elements of the distribution system including the heat pump, the buffer tank, the DHW, the ventilation recovery system and the three way valves that allow for the five working modes. Upon manufacturing the energy generating panel and specifying commercially available products for the distribution system, all the elements were installed 
on the Kubik building, a real scale testing building located in northern Spain. In parallel, the energy generating panel was taken to laboratory thermal testing.

\section{Validation of the BASSE energy generating panel and system}

This section presents the validations that were carried out through testing and implementation of the BASSE components. At the panel level the energy generating sandwich panel underwent thermal testing while at the building level all the components were installed into the Kubik building. The generated experimental data was used to validate the simulation tool and generate data on an annual basis so as to ultimately, calculate the KPIs of the BASSE system. The following sections provide a further description.

\subsection{Thermal testing of the energy generating panel}

The energy generating panel with parallel pipework was tested at Tata Steel laboratories in Rotherham in a thermal cycling test rig that uses infrared lamps that gradually apply heat. Thermocouples attached to the sandwich panel were used throughout the test to measure the input $\mathrm{T}_{\text {Low }}$ and the output $\mathrm{T}_{\text {Med }}$ temperature of the circulating liquid, as well as the temperature of the architectural cover sheet on the external $\mathrm{T}_{\text {Outer }}$ and internal $\mathrm{T}_{\text {Inner }}$ side. These latter ones were placed at the middle of the panel. The rate at which the circulating liquid flows $\left(\dot{\mathrm{m}}_{1}\right)$, was measured at various intervals by using a measuring jug. Heat was applied so that the skin reaches a stable temperature $\mathrm{T}_{\text {Max }}$ which is then sustained while the circulating liquid flow is turned on and the target flow rate is achieved. The test was carried out at a flow rate of about $0.10 \mathrm{~kg} / \mathrm{s}$ and a flow velocity of about 0.35 $\mathrm{m} / \mathrm{s}$ which is below the recommended value of $2.4 \mathrm{~m} / \mathrm{s}$ for safety and wear reasons. A total of four tests at target temperatures $\mathrm{T}_{\text {Max }}$ of $40^{\circ} \mathrm{C}, 60^{\circ} \mathrm{C}, 80^{\circ} \mathrm{C}$ and $100^{\circ} \mathrm{C}$ were conducted and results are presented in Table 7. On this table $\mathrm{T}_{\text {Med,test }}$ is the experimental measured value of the output temperature of the circulating liquid at a specific flow rate while $\mathrm{T}_{\text {Med,pred }}$ is the predicted value by the thermal analysis incorporated into the computer aid simulation tool. The table also shows the difference between the output and input temperature $\left(\mathrm{T}_{\text {Med-TLow }}\right)$ for the tests and theoretical predictions, $\Delta_{\mathrm{t}, \text { est }}$ and $\Delta_{\mathrm{t} \text {,pred }}$ respectively, and the overall error determined as $\left(\mathrm{T}_{\text {Med,test }}-\mathrm{T}_{\text {Med,pred }}\right) / \Delta_{\mathrm{t}, \text { test }}$. A typical temperature to time plot is presented in Figure 9 showing the temperature at different locations of the panel where it is observed an excellent agreement between the predicted curve by ANSYS CFX and experimental response. An example of the test set up at $\mathrm{T}_{\mathrm{Max}}$ and associated thermal image is presented in Figure 10. 
Table 7. Results of the thermal testing of the energy generating panel with parallel pipework and architectural flat cover

\begin{tabular}{ccccccccccc}
\hline \multirow{2}{*}{ Test } & $\begin{array}{c}\text { Flow Rate Flow Velocity } \\
(\mathrm{Kg} / \mathrm{s})\end{array}$ & $\begin{array}{c}\left.\mathrm{T}_{\text {Low }} / \mathrm{s}\right) \\
\end{array}$ & $\mathrm{T}_{\text {Max }}$ & $\mathrm{T}_{\text {Med,test }}$ & $\mathrm{T}_{\text {Med,pred }} \Delta_{\mathrm{t} \text { test }} \Delta_{\mathrm{t} \text {,pred }}$ & $\begin{array}{c}\text { Error } \\
\%\end{array}$ & $\begin{array}{c}\text { Avg } \\
\% \text { Error }\end{array}$ \\
\hline 1 & 0.107 & 0.35 & 12.16 & 42.30 & 13.21 & 13.24 & 1.05 & 1.07 & $-2.8 \%$ & \\
\hline 2 & 0.103 & 0.34 & 12.28 & 61.35 & 13.79 & 14.07 & 1.51 & 1.80 & $-18.7 \%$ & $-7.4 \%$ \\
\hline 3 & 0.1 & 0.33 & 12.22 & 81.36 & 14.73 & 14.82 & 2.51 & 2.60 & $-3.6 \%$ & \\
\hline 4 & 0.1 & 0.33 & 12.22 & 100.43 & 15.39 & 15.53 & 3.17 & 3.32 & $-4.6 \%$ & \\
\hline
\end{tabular}

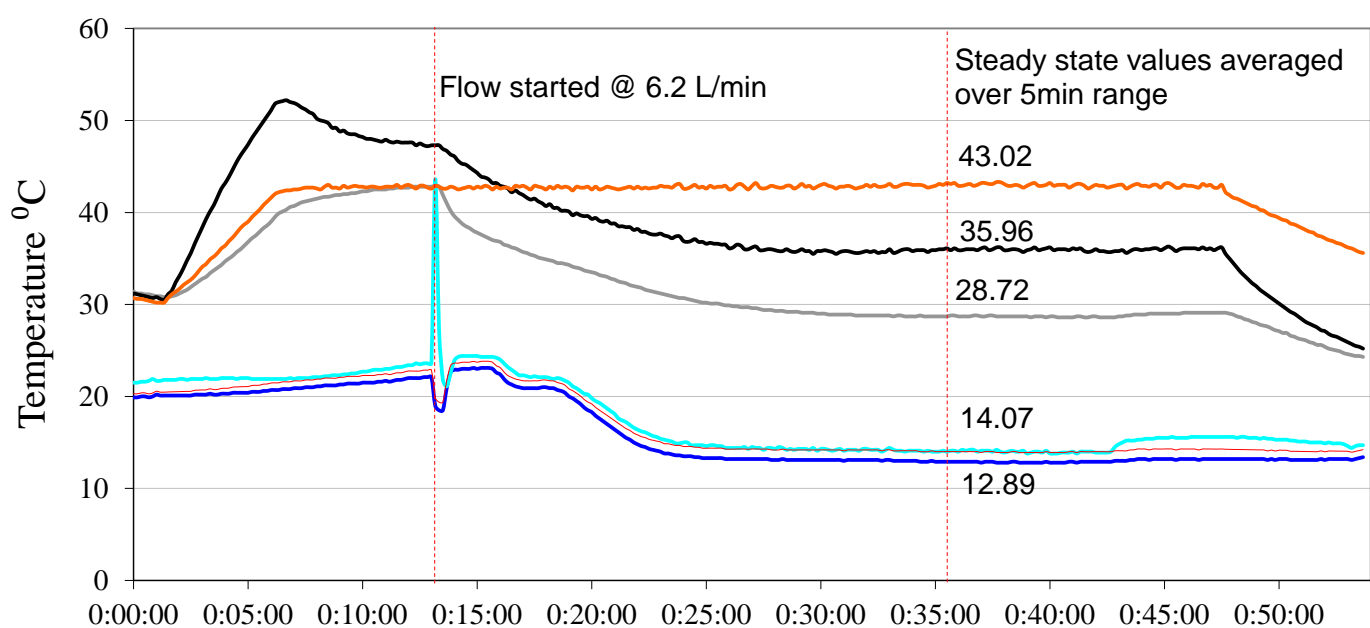

Time (min)

— Water in $\left({ }^{\circ} \mathrm{C}\right)$ - Water out $\left({ }^{\circ} \mathrm{C}\right)$ - Inside panel $\left({ }^{\circ} \mathrm{C}\right)$ - Outside panel $\left({ }^{\circ} \mathrm{C}\right)-$ Control TC $\left({ }^{\circ} \mathrm{C}\right)$ - $\operatorname{predicted}\left({ }^{\circ} \mathrm{C}\right)$

Figure 9. Thermal results at $\mathrm{T}_{\text {Max }}$ of $40^{\circ} \mathrm{C}$ (test 1)
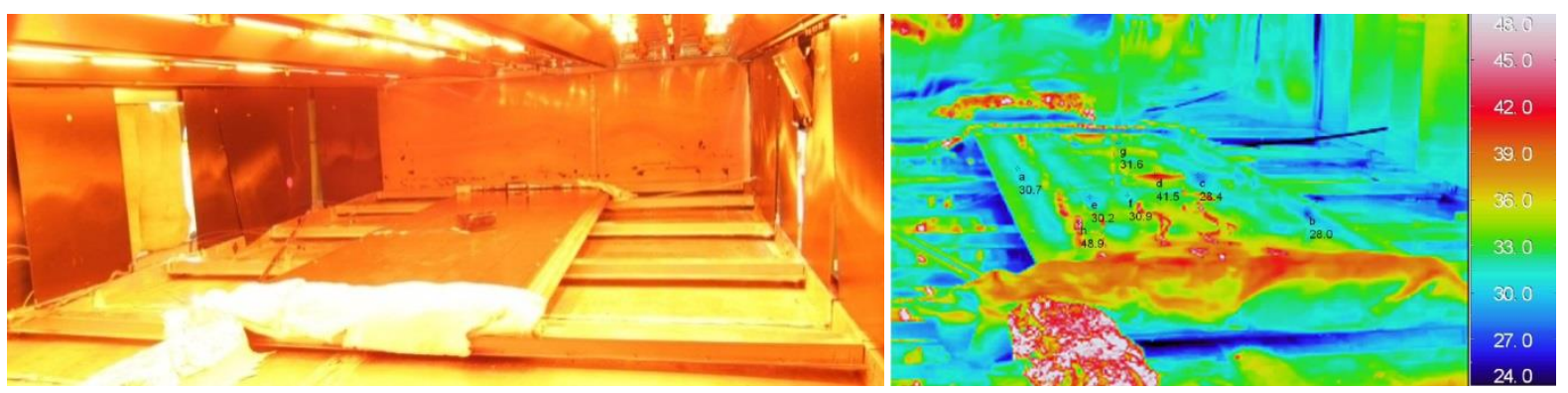

Figure 10. Energy generator in the thermal rig (left) and thermal image of Test 2 (right)

The tests showed that the energy generating panel does work. The results show that the predicted output temperature $\mathrm{T}_{\text {Med,pred }}$ is always higher than the experimental one $\mathrm{T}_{\text {Med,pred }}$ and therefore building on this, it is recommended to take the simulation values predicted by the simulation tool as an upper bound. Although not presented herein but available in the final project report [51], thermal tests were also carried out on the energy generating panel incorporating the horizontal and vertical serpentine pipework arrangements results of which showed a higher deviation between $\mathrm{T}_{\text {Med,test }}$ and $\mathrm{T}_{\text {Med,pred. }}$.

During the manufacture of the panel, it was observed that the thin-walled nature of the architectural cover makes it liable to buckling and distortion if fixed with an unsuitable method. This latter problem was more evident after subjecting the panel to thermal testing. Upon assessing various methodologies, screw fixings were the preferred option not only to ensure a good finishing but it was also found that 
this method provides the best heat transmission between the cover sheet and the pipework. However, screw fixings did not entirely removed distortion of the architectural cover sheet. Building on this, the fixing method was suggested as future research beyond the BASSE project.

\subsection{Implementation into Kubik building}

All the elements developed during the BASSE project were brought together at Kubik, a real scale testing building located in northern Spain with an average annual sum of $1300 \mathrm{kWh} / \mathrm{m}^{2}$ of horizontal radiation. A total of 6 panel prototypes (i.e. $18 \mathrm{~m}^{2}$ ) were retrofitted into the South oriented façade of the building, see Figure 11 (a). The heat pump system was set up in a $12.5 \mathrm{~m}^{2}$ utility room as shown in Figure 11 (b) with the heat pump in the middle, the buffer tank on the right and the DHW tank on the left. Including the living space shown in Figure 11 (c), the total plan area of the building is $67.9 \mathrm{~m}^{2}$. The following describes the remaining elements that were installed in the building as shown in Figure 12 [52]: two supply air modules to heat/cool the living space; two exhaust air modules to recover energy from exhaust air; ventilation pipes shown as green conducts in Figure 12 with arrows in blue and red representing external cool air and heated air respectively; an inertia tank labelled as UKV 40 placed on top of the heat pump; fluid conductions shown in red (hot), cold (blue) and mixed (orange); ten temperature sensors, two volumetric flow sensors and three heat meters to monitor energy balances; seven actuators to reverse the heat pump and enable the five possible working modes; and eight programmable logic controllers (PLCs) that control the BASSE system biomimetically.

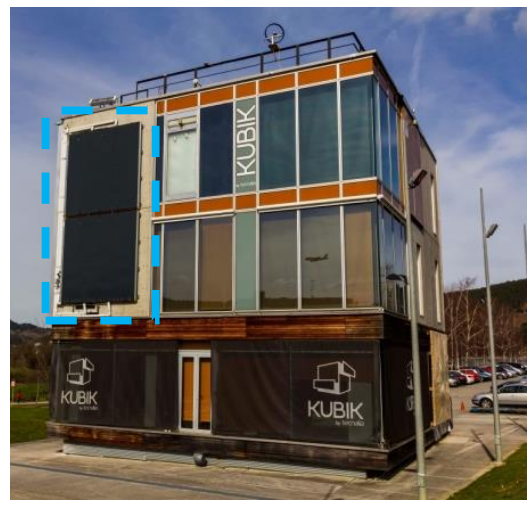

(a)

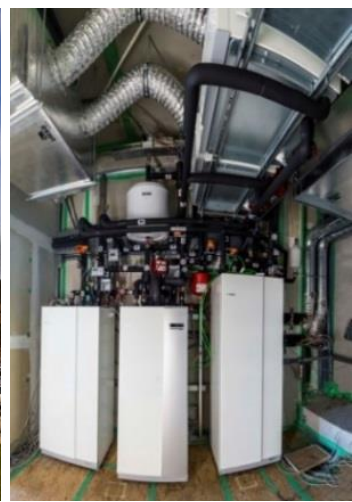

(b)

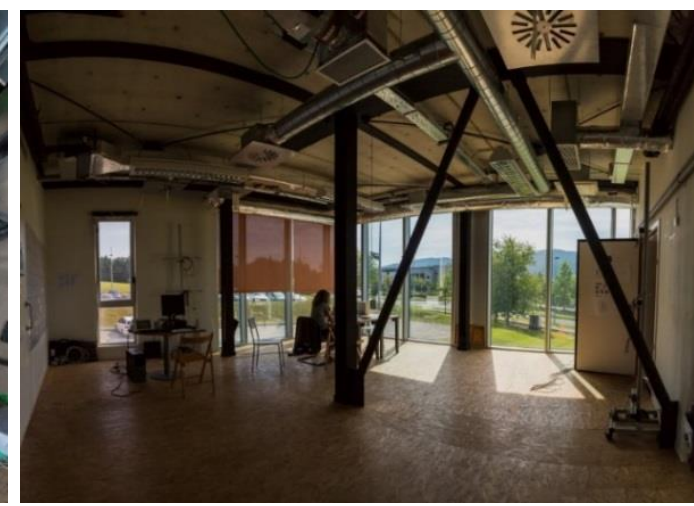

(c)

Figure 11. Kubik implementation: energy generating panels (a), arrangement of heat pump system within the utility room (b) and living space (c)

The PLCs, temperature sensors, valves, actuators flow-meters and heat-meters made up the control management system of BASSE which was developed to govern the interrelation between the energy generating panel and the heat pump. The control system was built on five requirements including safety working conditions, required five working modes, device availability check (i.e. check if a change of a working mode is possible before implementing the change), energy efficiency through target values definition and overall stability. For this purpose, a block-structured programming code 
was developed and implemented into Kubik. The logics behind the developed control system were tailored to the BASSE elements implemented in the Kubik building and as such, alteration of any element would therefore require reprogramming the control system. For this reason the code is not presented herein although a detailed description can be found in [52]. The present version of the control system is valid for application to buildings similar to Kubik.

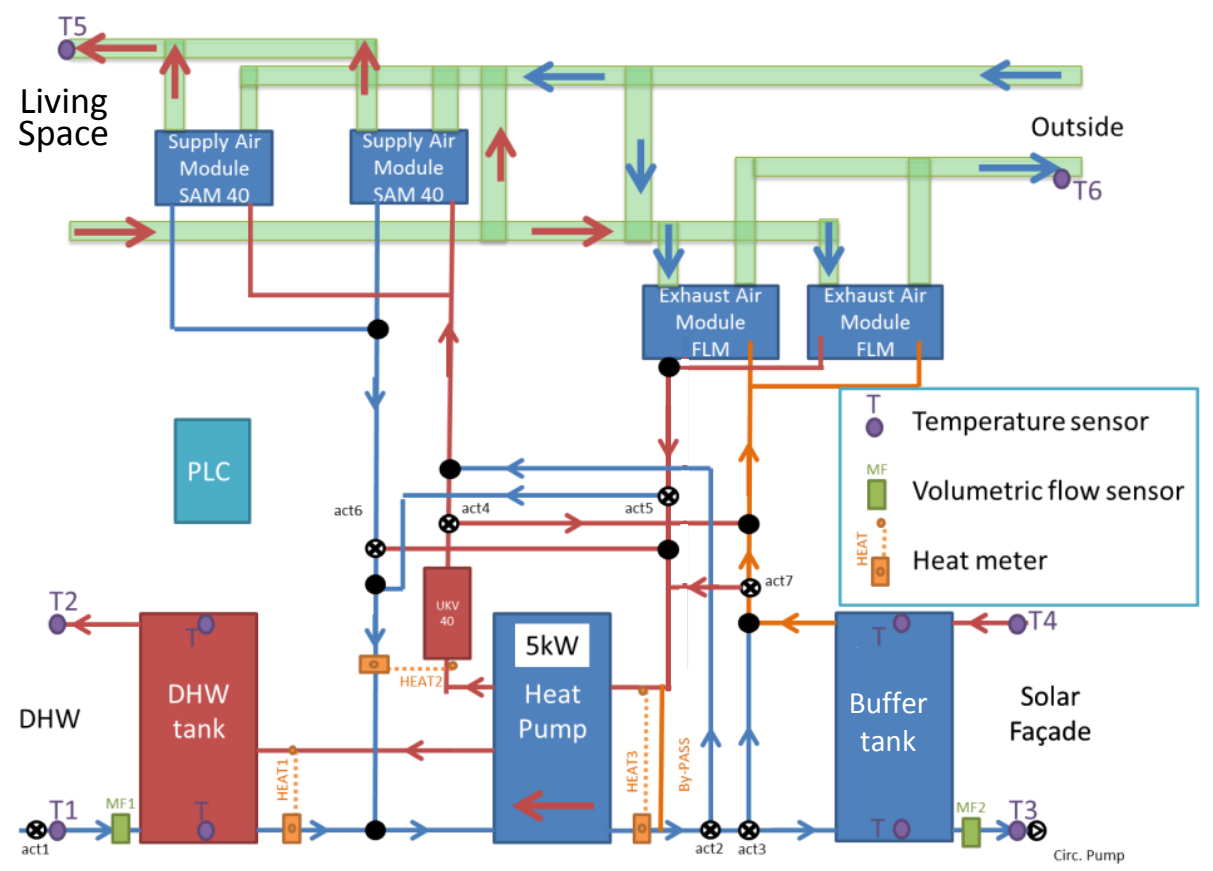

Figure 12. Schematic plan layout of the elements implemented into Kubik building [52]

\subsection{Results of the validation activity at Kubik}

The implementation of all the elements of the BASSE system was successfully completed in March 2016. This exercise was not only intended to validate the performance of the system but also to implement structural designs and put in practice installation procedures developed during the BASSE project. The rate of installation of the BASSE energy generating panels based on a modular solution (i.e. pipework and cover sheet assembled off-site) was estimated at $12-18 \mathrm{~min} / \mathrm{m}^{2}$ which is a competitive installation rate compared to other technologies for envelopes such as ventilated façades $\left(17-45 \mathrm{~min} / \mathrm{m}^{2}\right)$, metallic trays $\left(18-25 \mathrm{~min} / \mathrm{m}^{2}\right)$ and sandwich panels $\left(11-15 \mathrm{~min} / \mathrm{m}^{2}\right)$. The rate of installation for the hydraulic connections between the energy generating panel and buffer tank was estimated in the range of $15-40 \mathrm{~min} / \mathrm{m}^{2}$.

Prior to commissioning, an initial calibration of the buffer and heat tank was carried out for which target values from the KPI list as well as simulation results were taken into consideration. Overall, good agreement was achieved between the numerical and experimental tests [52].

Data was subsequently collected for 21 days between April and June 2016 when the BASSE system was running in various operational modes throughout the day. An example of the performance of the 
energy generating panel is shown in Figure 13 where temperatures in the skin of the panel, the buffer tank and ambient air are shown throughout the course of a day in June along with the irradiation. This figure shows that on that day when a maximum ambient temperature $\left(\mathrm{T}_{\mathrm{amb}}\right)$ of $25.3{ }^{\circ} \mathrm{C}$ and $435 \mathrm{~W} / \mathrm{m}^{2}$ irradiance was registered, the architectural cover of the energy generating panel was observed to reach a temperature of $46.9^{\circ} \mathrm{C}\left(\mathrm{T}_{\text {skin }}\right)$. The thermal energy was subsequently deployed into the buffer tank and for that particular example, a steady temperature increase over the course of $5: 14$ of up to $35.9{ }^{\circ} \mathrm{C}$ $\left(\mathrm{T}_{\text {tank }}\right)$ was registered.

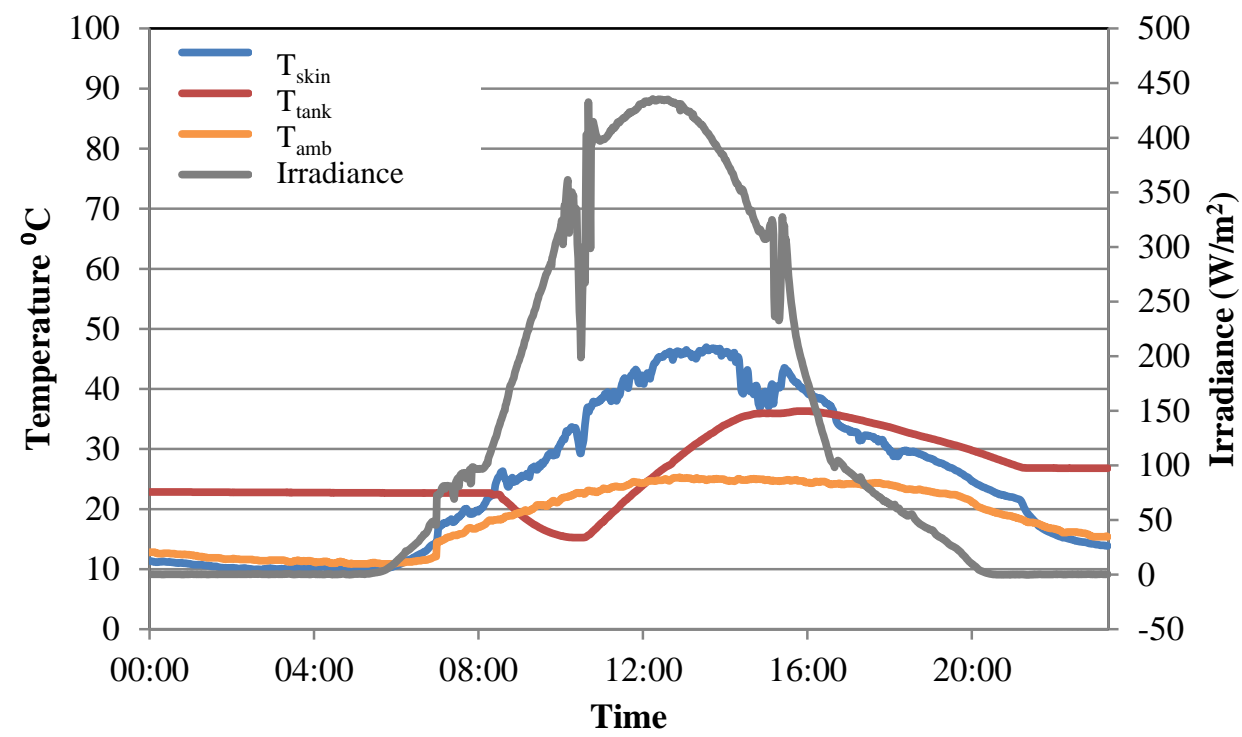

Figure 13. Temperature values in the panel and buffer tank for a day in June

The main results for the complete system are presented in Table 8 where the following parameters are reported: the total daily irradiance; the energy extracted from the energy generating panel $\mathrm{E}_{\text {harvest }}$; the average irradiance during harvesting period; the efficiency with respect to the total available irradiance; and the efficiency with respect to the harvesting period. A graphical representation of the relationship between the daily irradiance and efficiency is shown in Figure 14 where it is observed no correlation and scatter.

Table 8. Performance of the collector

\begin{tabular}{ccccccc}
\hline Day & $\begin{array}{c}\text { Harvest } \\
\text { Period (hour) }\end{array}$ & $\begin{array}{c}\text { Daily } \\
\text { Irradiance } \\
\left(\mathrm{Wh} / \mathrm{m}^{2}\right)\end{array}$ & $\begin{array}{c}\mathrm{E}_{\text {harvest }} \\
(\mathrm{kJ})\end{array}$ & $\begin{array}{c}\text { Average } \\
\text { Irradiance during } \\
\text { harvesting period } \\
(\mathrm{W} / \mathrm{m} 2)\end{array}$ & $\begin{array}{c}\text { Efficiency } \\
\text { compared to } \\
\text { daily irradiance } \\
(\%)\end{array}$ & $\begin{array}{c}\text { Efficiency } \\
\text { compared with } \\
\text { harvesting } \\
\text { period }(\%)\end{array}$ \\
\hline $28 / 04 / 2016$ & $12: 26-16: 48$ & 1804.63 & 16638.21 & 238.07 & 14.2 & 36 \\
$02 / 05 / 2016$ & $09: 33-15: 57$ & 4078.33 & 21120.97 & 488.98 & 8.0 & 15 \\
$03 / 05 / 2016$ & $09: 42-16: 18$ & 3259.53 & 11569.95 & 361.85 & 5.5 & 11 \\
$05 / 05 / 2016$ & $10: 12-14: 03$ & 3134.02 & 12347.57 & 340.91 & 6.1 & 21 \\
$10 / 05 / 2016$ & $6: 56-19: 58$ & 2954.82 & 59282.58 & 225.36 & 31.0 & 45 \\
$13 / 05 / 2016$ & $9: 54-17: 39$ & 1641.37 & 51924.61 & 193.73 & 48.8 & 77 \\
$19 / 05 / 2016$ & $06: 40-15: 46$ & 823.75 & 18368.17 & 73.89 & 34.4 & 61 \\
$21 / 05 / 2016$ & $6: 16-15: 02$ & 2610.77 & 18758.49 & 274.08 & 11.1 & 17 \\
$22 / 05 / 2016$ & $9: 30-15: 45$ & 2669.68 & 16293.39 & 310.55 & 9.4 & 19
\end{tabular}




\begin{tabular}{ccccccc}
\hline Day & $\begin{array}{c}\text { Harvest } \\
\text { Period (hour) }\end{array}$ & $\begin{array}{c}\text { Daily } \\
\text { Irradiance } \\
\left(\mathrm{Wh} / \mathrm{m}^{2}\right)\end{array}$ & $\begin{array}{c}\mathrm{E}_{\text {harvest }} \\
(\mathrm{kJ})\end{array}$ & $\begin{array}{c}\text { Average } \\
\text { Irradiance during } \\
\text { harvesting period } \\
(\mathrm{W} / \mathrm{m} 2)\end{array}$ & $\begin{array}{c}\text { Efficiency } \\
\text { compared to } \\
\text { daily irradiance } \\
(\%)\end{array}$ & $\begin{array}{c}\text { Efficiency } \\
\text { compared with } \\
\text { harvesting } \\
\text { period }(\%)\end{array}$ \\
\hline $02 / 06 / 2016$ & $9: 17-13: 55$ & 1938.38 & 22493.85 & 243.77 & 17.9 & 15 \\
$09 / 06 / 2016$ & $11: 27-15: 35$ & 2272.37 & 3765.53 & 369.12 & 2.6 & 5 \\
$10 / 06 / 2016$ & $11: 41-14: 49$ & 1172.93 & 3897.28 & 173.12 & 5.1 & 16 \\
$20 / 06 / 2016$ & $9: 16-16: 36$ & 3035.08 & 37459.04 & 329.01 & 19.0 & 35 \\
$21 / 06 / 2016$ & $08: 46-16: 14$ & 3044.94 & 37363.50 & 323.88 & 18.9 & 34 \\
\hline Mean & & 2460.04 & 23663.08 & 281.88 & 17 & 29 \\
\hline COV & & 0.351 & 0.684 & 0.348 & 0.773 & 0.679 \\
\hline \hline
\end{tabular}

With regards to the heat pump, the results were used to quantify its performance when connected to the energy generating panel through the buffer tank. The COP values of the heat pump turned out very competitive with COPs ranging from 4.8-5.5 for DHW production, 3.2-4.4 for heating production and in between 2.0-3.1 for cooling production. As shown in Figure 15, the COP for both DHW and heating production are well above the target value of 3 .

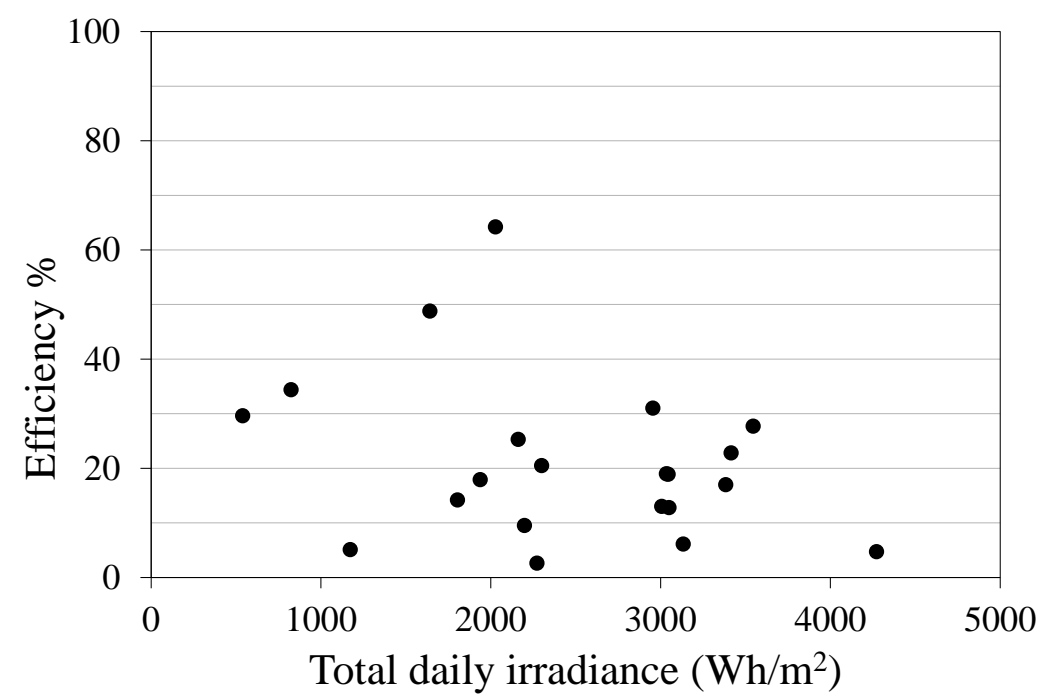

Figure 14. Relationship between efficiency of the complete system and daily irradiance

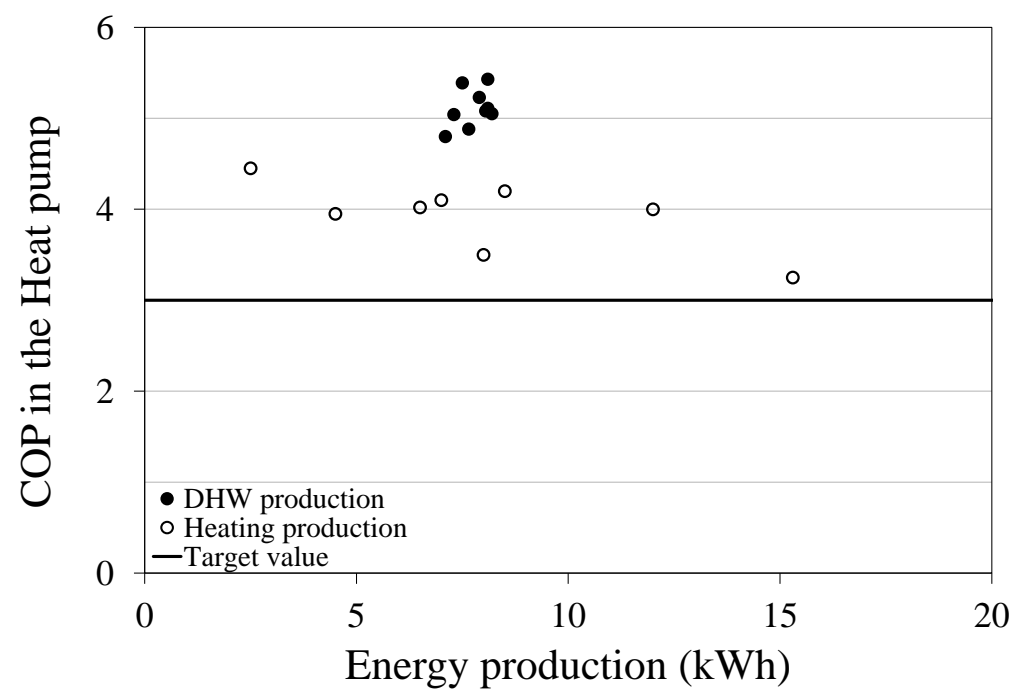

Figure 15. COP in the Heat pump for DHW and heating production 
The efficiency of the system was determined in terms of the renewable energy share to cover the load demands of the building. Table 9 presents the renewable energy share of the energy generating panel which on average for the selected days is $59.56 \%$.

Table 9. Performance of the collector

\begin{tabular}{|c|c|c|c|c|c|c|c|c|c|c|}
\hline \multirow[b]{2}{*}{$\begin{array}{l}\text { Day of } \\
' 16\end{array}$} & \multicolumn{2}{|c|}{ Totals (kWh) } & \multirow[b]{2}{*}{$\begin{array}{c}\text { Ratio } \\
(\%)\end{array}$} & \multicolumn{3}{|c|}{ Production $(\mathrm{kWh})$} & \multirow{2}{*}{$\begin{array}{c}\text { Total } \\
\text { Electricity } \\
\text { Consumption } \\
(\mathrm{kWh}) \\
\end{array}$} & \multirow[b]{2}{*}{$\begin{array}{l}\text { Daily } \\
\text { COP }\end{array}$} & \multicolumn{2}{|c|}{ Energy share } \\
\hline & $\begin{array}{c}\text { Daily } \\
\text { Irradiation }\end{array}$ & $\begin{array}{l}\text { Energy } \\
\text { collected }\end{array}$ & & DHW & Heating & Cooling & & & Electricity & Renewable \\
\hline $05 / 05$ & 56.41 & 3.43 & 6.1 & 5.5 & - & 2.7 & 3.5 & 1.8 & 42.1 & 57.9 \\
\hline $09 / 05$ & 41.40 & 8.48 & 20.5 & 13.2 & 3.1 & - & 7.4 & 3.7 & 45.1 & 54.9 \\
\hline $10 / 05$ & 53.19 & 16.47 & 31.0 & 23.5 & 6.9 & 2.6 & 10.7 & 4.2 & 32.5 & 67.5 \\
\hline $11 / 05$ & 39.58 & 3.75 & 9.5 & 17.2 & 7.9 & - & 8.0 & 4.4 & 31.7 & 68.3 \\
\hline $13 / 05$ & 29.54 & 14.42 & 48.8 & 8.1 & 0.3 & 6.9 & 6.3 & 1.7 & 41.0 & 59.0 \\
\hline $17 / 05$ & 61.48 & 14.04 & 22.8 & 18.5 & 4.3 & - & 12.1 & 2.6 & 52.8 & 47.2 \\
\hline $19 / 05$ & 14.83 & 5.10 & 34.4 & 1.6 & 20.3 & - & 11.3 & 3.6 & 51.6 & 48.4 \\
\hline $30 / 05$ & 38.91 & 9.84 & 25.3 & 30.8 & 0.8 & - & 9.2 & 3.9 & 29.1 & 70.9 \\
\hline $01 / 06$ & 9.71 & 2.87 & 29.6 & 7.5 & 1.0 & - & 3.2 & 2.3 & 38.1 & 61.9 \\
\hline Mean & 38.34 & 8.71 & 25.3 & 13.99 & 5.58 & 4.07 & 7.97 & 3.13 & 40.44 & 59.56 \\
\hline $\mathrm{COV}$ & 0.438 & 0.570 & 0.481 & 0.633 & 1.104 & 0.493 & 0.381 & 0.313 & 0.198 & 0.134 \\
\hline
\end{tabular}

In order to be able to compare the target values of the KPIs list for the energy generating panel and having validated the simulation tool at the calibration stage, numerical results were generated upon which annual values were determined. After numerical simulations were performed, the following results were obtained:

- Total thermal energy delivered by the BASSE system: $5818.22 \mathrm{kWh} /$ year.

- Total electricity consumed by the heat pump, solar pump and ventilation modules: 1737.5 $\mathrm{kWh} / \mathrm{year}$.

- Renewable share of $77 \%$ for covering the loads.

- Total energy harvested by the energy generating panel: $3321.14 \mathrm{kWh} / \mathrm{year}$ (30.4\% efficiency).

\subsection{KPIs calculation}

Following the implementation at Kubik, KPIs were calculated within the scope of the validation activity. The following describes a comparison of the calculated KPIs against the values set out at the development stage of the project.

At the system level, the system was deemed easy to integrate into Kubik though additional detailing is needed for implementation into more complex façade buildings. The carbon footprint during manufactured was not quantified, however, since the materials used are conventional no major issues are expected. The ease of maintenance was not possible to quantify due to the short period of time of the validation activity but it is expected to be similar to a sandwich panel. One aspect that needs is to be further assessed is the degradation of the panel due to thermal changes. The manufacturability of 
the energy generating panel was studied in [40] through the use of Flexsim simulation software where it was concluded that the production of a solar panel is in the range of 33-46 minutes. With reference to Table 1, note that no target value was defined.

At the energy generating panel level, the annual yield and thermal efficiency were determined based on the renewable energy share. The obtained annual yield without the contribution of the solar tank and energy recovery system was $184.5 \mathrm{kWh} / \mathrm{m}^{2}$ which is lower than the target value of $300 \mathrm{kWh} / \mathrm{m}^{2}$. The thermal efficiency was observed to be very variable and quite dependant on the working mode. An average annual value of $30.4 \%$ was estimated.

With regards to the energy storage tank, the parameters measured were the energy density of the circulating liquid, the temperature at which energy is stored and the temperature at which energy is released. The obtained values were $15-45 \mathrm{kWh} / \mathrm{m}^{3}$ which is within the target range, $5-25^{\circ} \mathrm{C}$ and $5-$ $25^{\circ} \mathrm{C}$, respectively. The target value for the temperature at which energy is stored and released were $>20^{\circ} \mathrm{C}$ and $<20^{\circ} \mathrm{C}$, respectively. Considering the implementation at Kubik, it was possible to store energy under $20^{\circ} \mathrm{C}$ with the proviso that when the storage tank is working at its lower limit near to $0^{\circ} \mathrm{C}$ an energy input is provided. The energy tank could also release energy for temperature values above $20^{\circ} \mathrm{C}$ when it is fully charged though the safety device installed with a dead band of $5^{\circ} \mathrm{C}$ would prevent this from happening.

Finally, the measured values of the COP and EER of the heat pump and associated heating and cooling system were in the range of 4.1-4.6 (for heating and DHW production) for the former and 3.35 for the latter. There values are well above the $>3.0$ target value for the COP and $>2.0$ target value for the EER.

\section{Conclusions}

This article has presented a new BIST system based on steel sandwich panels that deploys solar energy into a buffer tank for further production of heating, cooling and domestic hot water through the use of a heat pump. The system was developed to operate in southern, temperate and northern climatic regions of Europe under the framework of the BASSE project. The locations selected to represented these climatic regions were Madrid, Leicester and Malmö. A set of KPIs and system requirements were drawn upon which to base the development of all the components of system. Following an assessment of existing technologies, the BASSE system was specified by using ANSYS CFX along with a simulation tool that was also developed during the project. The components of the system were successfully validated through thermal testing and real scale implementation into Kubik, a testing building located in northern Spain. Simulation results were used to size the elements that were fitted into Kubik which were found to closely match experimental data during the building commissioning stage thereby enabling to confirm the accuracy of the simulation tool. Having completed the 
implementation into Kubik, data was collected during 21 days while the BASSE system was running in different modes. Experimental data was used to determine the KPIs of the implemented system which were discussed based on comparisons made against the target values defined at the development stage. The resulting calculations showed that the energy generating panel generates an annual yield of $184.5 \mathrm{kWh} / \mathrm{m}^{2}$ and has an average annual thermal efficiency value of $30.4 \%$. The COP of the heat pump was estimated to be in the range of 4.1 - 4.6 for heating and DHW production while the EER was 3.35 .

The applicability of the BASSE system to residential buildings located in the three abovementioned regions was studied through numerical simulation by using the developed numerical tool. A target building was defined for this purpose. Simulation results showed that a residential building with 35 BASSE energy generating panels and subject to the climate of Madrid can be considered NZEB while 45 BASSE panels are required to make a building located in Leicester NZEB. A numerical simulation was also undertaken for a commercial building with 160 BASSE panels results of which showed that only $1 \%$ of energy is needed to complement the energy generated by the BASSE system to meet a NZEB. The cost of a 35 and 45 BASSE panel installation was estimated at $21852 €$ and $23524 €$, respectively. A total of $42752 €$ was the cost of a 160 panel installation. Overall, a payback period of about 6.4-7.3 year was estimated for residential buildings. For commercial applications the payback period was 0.7 years and therefore, the BASSE system seems more competitive from the economical aspect point of view for application to such type of buildings. However, note that within the framework of this project the simulation tool has only been validated for residential applications and therefore it is suggested for further research to conduct a validation of the BASSE system for application to commercial buildings.

The results of this project have been a step forward in the development of solar based systems that can be integrated into the façade of the building envelope. The BASSE project has considered exiting technologies to develop a new construction product thereby enabling immediate market penetration and ultimately the achievement of the GHG reduction targets. In its current form, the developed BASSE system is a prototype that has shown a high competitive performance.

\section{Acknowledgements}

The research leading to these results has received funding from the European Community's Research Fund for Coal and Steel (RFCS) under Grant Agreement No. RFSR-CT-2013-00026.

\section{References}

[1] International Energy Agency (2017). Energy Technology Perspectives.

[2] Directive 2009/28/EC (2009). On the promotion of the use of energy from renewable sources. 
[3] Directive 2010/31/EC (2010). On the energy performance of buildings.

[4] Marszal AJ, Heiselberg P, Bourrelle JS, Musall E, Voss K, Sartori I and Napolitano I, Zero energy building - a review of definitions and calculation methodologies. Energy and Buildings, 43(4), 971-979, 2011.

[5] Szalay Z and Zöld A, Definition of nearly zero-energy building requirements based on a large building sample, Energy Policy, 74, 510- 521, 2014.

[6] D'Agostino D, Assessment of the progress towards the establishment of definitions of Nearly Zero Energy Buildings (nZEBs) in European Member States. Journal of Building Engineering, 1, 20-32, 2015.

[7] Sartori I, Napolitano A, Voss K, Net zero energy buildings: a consistent definition framework. Energy and Buildings, 48, 220-32, 2012.

[8] Maslesa E, Jensen PA and Birkved M, Indicators for quantifying environmental building performance: A systematic literature review. Journal of Building Engineering, 19, 552-560, 2018.

[9] Mohamed A, Hasan A, Siren K, Fulfillment of net-zero energy building (NZEB) with four metrics in a single family house with different heating alternatives. Applied energy 114, 385- 399, 2014.

[10] Wang S, Yan C and Xiao F, Quantitative Energy Performance assessment methods for existing buildings. Energy and Buildings, 55, 873-888, 2012.

[11] Martinopoulos G, Life Cycle assessment of solar energy conversion systems in energetic retrofitted buildings. Journal of Building Engineering, 20, 256-263, 2018.

[12] Tsalikis G and Martinopoulos G, Solar energy systems potential for nearly net zero energy residential buildings. Solar Energy, 115, 743-756, 2015.

[13] Golić K and Kosorić V, General model of solar water heating system integration in residential building refurbishment - Potential energy savings and environmental impact. Renewable and Sustainable Energy Reviews, 15, 1533-1544, 2011.

[14] Yau YH and Lim KS, Energy analysis of green office buildings in the tropics - Photovoltaic system. Energy and Buildings, 126, 177-193, 2016.

[15] Colclough S and McGrath T, Net energy analysis of a solar combi system with Seasonal Thermal Energy Store. Applied Energy 147, 611-616.

[16] Cao S, Hasan A and Sirén K, Matching analysis for on-site hybrid renewable energy systems of office buildings with extended indices. Applied Energy, 113, 230- 247, 2014.

[17] Renewable energy: technologies and global markets - BCC Research; 2015.

[18] Quesada G, Rousse D, Dutil Y, Badache M and Hallé, A comprehensive review of solar facades. Opaque solar facades, Renewable and Sustainable Energy Reviews, 16, 2820-2832.

[19] Quesada G, Rousse D, Dutil Y, Badache M and Hallé, A comprehensive review of solar facades. Transparent and translucent solar facades, Renewable and Sustainable Energy Reviews, 16, 26432651.

[20] Hestnes A, Building Integration of solar energy systems, Solar energy. 67 (4-6). 181-187, 1999. 
[21] Kalogirou AS, Building integration of solar renewable energy systems towards zero or nearly zero energy buildings. International Journal of Low-Carbon Technologies, 10, 379-385, 2015.

[22] Maurer C, Cappel C and Kuhn TE, Progress in building-integrated solar thermal systems. Solar Energy, 154, 158-186, 2017.

[23] Biyik E, Araz M, Hepbasli A, Shahrestani M, Yao R, Shao Li, Essah E, Oliveira AC, Caño T, Rico E, Lechón JL, Andrade L, Mendes A, Atlı YB. A key review of building integrated photovoltaic (BIPV) systems. Engineering Science and Technology, an International Journal, 20, 833-858, 2017.

[24] Elguezabal P, Garay R and Martin K, Experimentation under real performing conditions of a highly integrable unglazed solar collector into a building façade. Energy Procedia, 122, 775-780, 2017.

[25] Malenkovic I, Definition of Performance Figures for Solar and Heat Pump Systems, Technical Report 5.1.3”, QAiST, Austrian Institute of Technology, 2012.

[26] Hadorn J, SHC 2012, IEA Solar and Heat Pump Systems, Solar Heating and Cooling Task 44 \& Heat Pump Programme Annex 38, Energy Procedia, 30, pp125-33, 2012.

[27] Wemhoner C, Afjei T, Seasonal performance calculation for residential heat pumps with combined space heating and hot water production (FHBB Method)", Research program heat pumping technologies, cogeneration, refrigeration, Final report, 2003.

[28] Solartechnik Prufung Forschung Collector Test results. Retrieved from http://www.solarenergy.ch/Kollektoren.84.0.html

[29] Johnson D. Red Rock Energy. Table of absorptivity and emissivity of common materials and coatings. http://www.solarmirror.com/fom/fom-serve/cache/43.html

[30] Posharp the resource for renewables. Photovoltaic panel efficiency and performance. Retrieved from http://posharp.com/photovoltaic/panelefficiency/database.aspx

[31] Matuska T, Performance and economic analysis of hybrid PVT collectors in solar DHW system", SHC 2013, International Conference on Solar Heating and Cooling for Buildings and Industry September 23-25, 2013, Freiburg, Germany, Energy Procedia, 48, 150 - 156, 2014.

[32] Eurostat. European commission database. Gas prices for household consumers - bi-annual data (from 2007 onwards). Retrieved from https://ec.europa.eu/eurostat/web/energy/data/database.

[33] Singhaputtangkul N, Low SP, Teo AL, Hwang BG, Knowledge-based Decision Support System Quality Function Deployment (KBDSS-QFD) tool for assessment of building envelopes. Automation in Construction, 35, 314-328, 2013.

[34] Singgih ML, Trenggonowati DL, Karningsih PD, Four phases Quality Function Deployment (QFD) by considering KANO concept, time and manufacturing cost, in the 2nd International Conference of Engineering and Technology Development, ICETD 2013, Indonesia.

[35] Perry, T., Harper, C.S. \& Parkin, P. (2014). Deliverable 2: Concept development. Building Active Steel Skin Envelope. RFSR-CT-2013-00026.

[36] Brown, C., Perisoglou, E., Hall, R. \& Stevenson, V. (2014). Transpired solar collector installations in Wales and England. SHC 2013, International Conference on Solar Heating and Cooling for Buildings and Industry September 23-25, 2013, Freiburg, Germany. Energy Procedia. 48. pp. 18-27. 
[37] Pugh S, Clausing D and Andrade R, Creating innovative products using total design: the living legacy of Stuart Pugh, Addison-Wesley Publishing Company, USA, 1996.

[38] Harper CS, Francesconi G, Holmber T and Elguezabal P, Deliverable 3: Integrated first design of the envelope system. Building Active Steel Skin Envelope. RFSR-CT-2013-00026, 2015.

[39] Bertucelli L. and Harper CS, Deliverable 5: Manufacturing methodologies. Building Active Steel Skin Envelope. RFSR-CT-2013-00026, 2015.

[40] Bock M and Harper CS, Deliverable 8: Production process simulation. Building Active Steel Skin Envelope. RFSR-CT-2013-00026, 2016.

[41] Martinopoulos G, Papakostas KT and Papadopoulous AM, A comparative review of heating systems in EU countries, based on efficiency and fuel cost. Renewable and Sustainable Energy Reviews, 90, 687-699, 2018.

[42] Ortega-Izquierdo M, Paredes-Salvador A and Montoya-Rasero C, Analysis of the decision making factors for heating and cooling systems in Spanish households. Renewable and Sustainable Energy Reviews, 100, 175-185, 2019.

[43] Perry T, Harper CS and Parkin P. Deliverable 2: Concept development. Building Active Steel Skin Envelope. RFSR-CT-2013-00026, 2014.

[44] Martinopoulos G, Papakostas KT and Papadopoulous AM, Comparative analysis of various heating systems for residentialbuildings in Mediterranean climate. Energy and Buildings, 124, 79-87, 2016.

[45] Phillips R, Troup L, Fannon D, Eckelman MJ, Do resilient and sustainable design strategies conflict in commercial buildings? A critical analysis of existing resilient building frameworks and their sustainability implications, Energy and Buildings, 146, 295-311, 2017.

[46] Elguezabal P and Holmberg T, Deliverable 4: Simulation tool of the system.Building Active Steel Skin Envelope. RFSR-CT-2013-00026, 2015.

[47] Basu C, Schiavon S and Bauman F, Sizing thermally activated building systems (TABS) a brief literature review and model evaluation. International Conference on Building Energy and Environment. Boulder, Colorado, 2012.

[48] Gwerder M, Lehmann B, Tödtli J, Dorer V and Renggli F, Control of thermally-activated building systems (TABS). Applied Energy, 85 (7), 565-81, 2008.

[49] Lehmann B, Dorer V and Koschenz M, Application range of thermally activated building systems tabs. Energy and Buildings, 39 (5), 593-8, 2007.

[50] TRNSYS 17. A TRaNsient System Simulation program. The University of Wisconsin, USA.

[51] Boudjabeur S, Harper CS, Bock M, Chica JA, Elguezabal P, Garay M, Perry T, Simpson K, Francesconi G, Svensson H, Holmberg T, Lindahl M, Bertucelli L, Vairo G, Fuster A, Gisbert J, Rodriguez P and Toledo C, Final Report. Building Active Steel Skin Envelope. RFSR-CT-201300026, 2017.

[52] Elguezabal P, Deliverable 7: Final component validation and demostration. Building Active Steel Skin Envelope. RFSR-CT-2013-00026, 2016. 
